TITLE:

\title{
Taxonomic studies on the Talitridae (Crustacea, Amphipoda) from Taiwan. -II. The genus Platorchestia
}

\author{
$\operatorname{AUTHOR}(\mathrm{S}):$
}

Miyamoto, Hisashi; Morino, Hiroshi

\section{CITATION:}

Miyamoto, Hisashi ... [et al]. Taxonomic studies on the Talitridae (Crustacea, Amphipoda) from Taiwan. - II. The genus Platorchestia. PUBLICATIONS OF THE SETO MARINE BIOLOGICAL LABORATORY 2004, 40(1-2): 67-96

ISSUE DATE:

2004-07-31

URL:

http://hdl.handle.net/2433/176317

RIGHT: 


\title{
Taxonomic studies on the Talitridae (Crustacea, Amphipoda) from Taiwan. II. The genus Platorchestia
}

\author{
Hisashi MiYamoto ${ }^{1)}$ and Hiroshi Morino ${ }^{2)}$ \\ 1) Kasumi 4-9, Maruoka-Chou, Sakai-Gun, Fukui Prefecture, 910-0231, Japan \\ ${ }^{2)}$ Department of Environmental Sciences, Ibaraki University, Mito, \\ 310-8512, Japan
}

\begin{abstract}
Four species of the genus Platorchestia Bousfield are described from Taiwan, e.g., $P$. pacifica n. sp., $P$. joi Stock and Biernbaum, 1994, $P$. japonica (Tattersall,1922) and $P$. humicola (Martens, 1868). The former two species, together with $P$. platensis (Krøyer, 1845) and $P$. munmui Jo, 1988 , compose a closely related species cluster. $P$. pacifica $\mathrm{n}$. $\mathrm{sp}$. was found on almost all the coast of the mainland and neighboring islands in Taiwan, while the other three species were found in the mainland north of $23.5^{\circ} \mathrm{N}$.
\end{abstract}

Key words: Platorchestia, Talitridae, Amphipoda, Taxonomy, Taiwan.

\section{Introduction}

As a second report of the serial taxonomic studies on Taiwanese Talitridae, the present paper deals with the species of Platorchestia Bousfield, 1982 found in the coastal areas, including supralittoral zones, grass land and small patches of leaf-litter, of the mainland and neighboring islands of Taiwan (see Miyamoto and Morino, 1999).

The first record of Platorchestia species from Taiwan has been given by Iwasa (1939) under the name of Orchestia platensis Krøyer 1845, which is now transferred to the genus Platorchestia. $P$. platensis, originally described from the south Atlantic, has long been believed to be a semicosmopolitan species (Morino, 1975; Bousfield, 1982), and has been recorded from various coastal regions of the Indo-Pacific (Chilton, 1921; Iwasa, 1939; Stephensen, 1945; Bulycheva, 1957; Morino, 1975; Bousfield, 1982; Myers, 1985; Moore, 1986; Kim \& Kim, 1987). Recently Bousfield (1982) resurrected the species Platorchestia crassicornis (Derzhavin, 1937) $(=P$. joi Stock and Biernbaum, 1994) described from the Russian coast of the Japan Sea, which has long been relegated to a junior synonym of $P$. platensis (e.g., Bulycheva, 1957). Jo (1988) made a comparison between the Atlantic specimens of $P$. platensis and the northwest Pacific material of " $P$. platensis". He concluded that both materials are clearly distinguishable and identified the northwest Pacific material to $P$. joi, casting serious doubt to the occurrence of $P$. platensis (Krøyer, 1845) from this region. He also erected a new supralittoral species $P$. munmui from Korea, which is close to $P$. platensis.

In hope of progress of taxonomy of these animals, aforementioned authors have tried to introduce new characters to settle taxonomic problems and put forth phylogenetic relationships. For instance, Bousfield (1982) paid attention to the cusps on pereopod dactyls; Jo (1988) suggested the specific diversity in fine structure of retinaculae of pleopods. Miyamoto and Morino (1999), in describing Talorchestia and Sinorchestia species, attempted to describe spines in detail for some parts of appendages. In this paper, we have paid attention to the type of spines and/or the arrangement in gnathopod 1 propod, maxilla 2 outer plate, maxilliped plates and uropod 3 ramus. The diversity of setae or spines has recently been noted and reviewed for amphipods on the basis of SEM observations by Oshel and Steel (1988) and Watling (1989). The present study has mainly been carried out with the aid of the light microscope. As a result of the present study, four Platorchestia species are identified, which will be given below. 


\section{Material and Methods}

The collection sites have been given in Miyamoto and Morino (1999). The materials were fixed in $4 \%$ formaldehyde, then transferred to $70 \%$ ethanol. Appendages of amphipods were mounted on slide glasses with the Hoyer's solution and examined under a light microscope at magnifying powers of 100-400. Observations of spines at a magnifying power 1000 were done after staining material in the acetocarmine solution with the glycerin. Appendages were illustrated with the aid of a camera lucida microscope attachment. In addition to Taiwanese material, the following ones were examined for comparison: a type specimens of Platorchestia humicola (from Kamakura, Japan), topotypic specimens of $P$. japonica (from Lake Biwa), a paratype of $P$. munmui (from Daebon, South Korea), and specimens of European $P$. platensis (from Kent, England).

The type material of Platorchestia pacifica n. sp. is deposited in the collection of the National Museum of Natural Science, Taichung, Taiwan, R.O.C. (NMNS). All other materials are deposited in Miyamoto's collection.

Types of spines are classified and named mainly by reference to Holmquist (1982), Oshel and Steel (1988) and Watling (1989). The newly introduced or renamed spines types that appeared in Miyamoto and Morino (1999) are as follows:

Blunt spines on maxilla 2, maxilliped: blunt-tipped, apically curved setae without ornamentation except apical pore (Fig. 1G). (= Smooth blunt spines in Miyamoto and Morino, 1999).

Smooth spines on uropod 3: shaft without ornamentation, nor apical pore (Fig. 2Ze).

Setulose sharp spines on maxilla 2: sharp spines with setules on the shaft, apical pore present; this type of spines comprises two sub-types: one with two rows of setules on the shaft (often one row of setules indiscernible) (Fig. $1 \mathrm{~F}, \mathrm{I}$ ), the another with a row of setules and a row of dense hairs along the side of the shaft (Fig. 1H).

Brush sharp spines on maxilla 2: sharp spines with hair brush-like ornamentation on the shaft, pore opened subapically (Fig. 1E).

Sheathed spines on maxilliped, gnathopod 1, etc: imbricated spines (imbricated setae in Holmquist, 1982) with collar-like sheath (Fig. 2c, d). Apical pore present. They resemble bifid spines (Fig. 2a, b), though are distinguished from the latter by lacking longitudinal stripes on the shaft. (= Trident spines and collar tipped spines in Miyamoto and Morino, 1999).

Dentition formula of maxilla 1 refers to the number of dentitions on each of the apical spinulate spines of the outer plate, from lateral to medial side.

\section{Systematics \\ Platorchestia Bousfield, 1982}

Platorchestia Bousfield, 1982: 26-27; Jo, 1988: 160-161; Richardson, 1991: 186; Morino \& Ortal, 1995: 825.

\section{Diagnosis}

Antenna 1 hardly exceeding peduncular article 4 of antenna 2, peduncular articles 1-3 subequal in length; flagellum shorter than peduncle. Antenna 2: peduncle strongly to barely incrassate in males; flagellum subequal to or shorter than peduncle.

Lacinia mobilis of left mandible 5-, occasionally 6-dentate (Jo, 1988). Maxilliped: lobe of outer plate, distal margin gently slanted; palp article 2 broad, with mediodistal lobe; palp article 3 as long as wide, rounded apically; palp article 4 small, masked by spines.

Male gnathopod 1: merus without tumescent hump; carpus with tumescent hump on posterodistal angle; propod tumescent posterodistally, dactyl subequal to or slightly longer than palm. Female gnathopod 1: merus to propod without tumescent hump; posterodistal part of propod weakly bulged, scabrous, palm very short, slightly oblique. Male gnathopod 2: propod large, palm notched, sinuous or gently curved; dactyl stout, slightly longer than palm. Female gnathopod 2: basis expanded 
anteroproximally; posterodistal corner of merus weakly tumescent or not tumescent; carpus with shallow tumescence posteriorly; propod tumescent posterodistally.

Pereopods 3-7 cuspidactylate; carpus of pereopod 4 shorter than that of pereopod 3; pereopods 5-7 heteropodous; basis with posterodistal lobe; merus broadened distally; pereopods 7 strongly to barely sexually dimorphic.

Coxal plate of pereopod 6, anterior margin of posterior lobe nearly vertical, anterodistal corner right angled or strongly curved.

Pleopods 1-3, peduncles with 2 retinaculae; rami subequal to or shorter than peduncle, multiarticulated.

Uropod 1: peduncle with short distolateral spine; outer ramus marginally bare, occasionally with a few spines. Uropod 2: inner ramus with spines on both margins. Uropod 3: ramus with 1 or 2 long bifid spines and 2-3 short spines (1 smooth spine and 1-2 bifid spines) apically.

Telson spade-shaped, apex notched, with apical and dorsal spines groups.

Brood plates 2-5 with simple tipped setae, brood plate 5 shortest.

\section{Remarks}

Twelve species, except enigmatic Platorchestia chathamensis Bousfield, 1982 and P. zachsi (Derzhavin, 1937), have so far been placed in this genus. The original diagnoses proposed by Bousfield (1982) emphasized the strong sexual dimorphism in antenna 2 and pereopods 6 and 7 for the member of this genus. However, these features do not hold in some of the terrestrial species (see Morino and Dai, 1990). Recent knowledge on this genus suggests that the member exhibit various degree of sexual dimorphism and the occurrence of intergrading forms. This genus comprises the following three groups based on development of sexual dimorphism:

Group 1: Antenna 2 and pereopods 6 and 7 strongly sexually dimorphic, represented by supralittral species: $P$. joi Stock \& Biernbaum $1994=P$. crassicornis (Derzhavin, 1937), P. munmui Jo 1988, P. pacifica n. sp., P. pachypus (Derzhavin, 1937), P. platensis (Krøyer, 1845).

Group 2: Antenna 2 sexually dimorphic, pereopods 6 and 7 never show sexual dimorphism, represented by semiterrestrial species: P. ashmoleorum Stock, 1996 and P. monodi (Martens et. al., 1986);

Group 3: Antenna 2 and pereopods 6 and 7 barely (or slightly) sexually dimorphic, represented by terrestrial species: $P$. humicola (Martens, 1868), P. japonica (Tattersall, 1922) and P. kaalensis (Barnard, 1955), P. lanipo (Richardson, 1991), P. pickeringi (Dana, 1853). Latter three species share slender maxilliped palps. As emphasized above, distinct spines types have been recognized and will be described in the descriptions of Taiwanese species. These characters are likely to be of taxonomic significance at the generic level. However, since the examination of these characters has not been done yet for the rest of species here treated, these characters are not included in the genetic diagnosis.

Key to Taiwanese and related species of Platorchestia

1) Antenna 2 and pereopod 7 strongly sexually dimorphic; flagellum of male antenna 2 is 0.9-1.5 times as long as peduncular article 5; inner plate of maxilla 2 with 20-30 blunt spines on distal margin; propod of male gnathopod 1 with bifid spines on lateral surface; palm of male gnathopod 2 sinuous or with protuberance

- Antenna 2 and pereopod 7 weakly or barely sexually dimorphic; flagellum of male antenna 2 is 1.8-2.2 times as long as peduncular article 5; inner plate of maxilla 2 with 15-20 blunt spines on distal margin; propod of male gnathopod 1 without bifid spines on lateral surface; palm of male gnathopod 2 smoothly convex

2) Dactyl of gnathopod 1 lacking denticle; propod of female gnathopod 1 with

3 longitudinal rows of 3-4 bifid spines on posterior margin and surface of lateral side; propod of male gnathopod 2 with a few spines on posterior margin; peduncles of pleopods with downward spine on outer distal angle 
- Dactyl of gnathopod 1 with denticle; propod of female gnathopod 1 with 2 longitudinal rows of 3-4 bifid spines on posterior margin and surface of lateral side; propod of male gnathopod 2 lacking posterior spines; peduncles of pleopods without downward spine

3) Coxal plates of pereopods 2-4 very shallow and wider than deep; pereopod 3 , carpus and propod short, each ca. 0.5 times as long as merus; pereopod 6 , posterior lobe of coxal plate lacking distal process on anterodistal corner

- Coxal plates of pereopods 2-4 as wide as or slightly wider than deep; each of carpus and propod of pereopod $3 \mathrm{ca} .0 .8$ times as long as merus; pereopod 6 , posterior lobe of coxal plate with distal process on anterodistal corner

4) Carpus of male pereopod 7 incrassate, laterally elliptic; propod palm of male gnathopod 2, notch situated at ca. 2/3 from dactyl hinge

- Carpus of male pereopod 7 incrassate, laterally oblong; propod palm of male gnathopod 2, notch situated at ca. $3 / 5$ from dactyl hinge ……................ P. pacifica (p. 76)

5) Rami of pleopods 0.8-0.9 times as long as peduncles; ramus of uropod $3 \mathrm{ca} .0 .7$ times as long as peduncle, with 2 long spines and a few short spines apically

- Rami of pleopods 0.5-0.6 times as long as peduncles; ramus of uropod 3 ca. 0.5-0.6 times as long as peduncle, with 1 long spine and a few short spines apically

P. humicola (p. 88)

\section{Platorchestia joi Stock \& Biernbaum 1994}

(Figs. 1-3, 15)

Talorchestia crassicornis Derzhavin, 1937: pp. 108-109, Pl. 3, 1.

Orchestia platensis; non Krøyer, 1845: Iwasa, 1939, pp. 275-261, figs. 1-3, pl. IX.

Platorchestia crassicornis (Derzhavin, 1937): Bousfield, 1982, p. 26; Jo, 1988, pp. 161-167, figs. 5-9. Platorchestia joi Stock \& Biernbaum, 1994: pp. 800 (proposed name for homonymous crassicornis).

\section{Material examined}

Seven males and 12 females from Fulung, 30 Jul. 1981; eight males and five females from Demao, 4 Aug. 1976; nine males and 29 females (17 ovig.) from Demao, 18 Aug. 1981.

\section{Description of male}

Body length 8-11 mm. Eyes medium large, subround. Inferior antennal sinus shallow. Antenna 1 (Fig. 2A) not reaching end of peduncular article 4 of antenna 2; flagellum 0.5-0.6 times as long as peduncle, 5-6-articulated. Antenna 2 (Fig. 2C) ca. 1/3 times as long as body length; peduncular articles 4 and 5 incrassate, with minute spines, peduncular article 5 is 1.8-2.0 times as long as article 4; flagellum 1.0-1.2 times as long as peduncular article 5, 14-16-articulated, 3-4 proximal articles coalesced, each article flat, decreasing distally in size, all articles with 4 groups of 3 spines.

Upper lip (Fig. 1N): deeper than wide, ventral margin pilose. Lower lip (Fig. 1O): inner shoulder and margin of central trough pilose. Left mandible (Fig. 1L): incisor 6-dentate, lacinia mobilis 5dentate, with 6 pappose spines. Right mandible (Fig. 1M): incisor 6-dentate; lacinia mobilis tricuspate, with 4 pappose spines (= lifting spines). Maxilla 1 (Fig. 1J, K): outer plate dentition formula, 2-2-4-4-4/5-4/5-5/6-5-5, with a row of fine spines along base of spinulate spines (= saw-like spines) on ventral side; palp minute, 2-articulated; inner plate narrow, with 2 long pappose spines at apex. Maxilla 2 (Fig. 1B, C, D): inner plate with 22-25 blunt spines on distal margin, with a row of 910 setulose sharp spines and 2 pappose spines on dorsal margin, and a row of 9-10 brush sharp spines on ventral margin; outer plate, distal margin with 15-16 blunt spines and a group of 4 spines (setulose sharp spine, blunt spine, setulose sharp spine, brush sharp spine) and with a row of 10-12 brush sharp 
spines on ventral margin, lacking setulose sharp spines on dorsal margin. Maxilliped (Fig. 1P, Q, R, S): inner plate with 3 unequal-sized spine-teeth and 4-5 pappose spines on distal margin, lobe of outer plate shorter than basal height, medial distal corner right-angled, with 5-6 pappose spines on dorsolateral margin, with 1 pappose spine, 2 rows of ca. 10 imbricated spines and ca. 10 blunt spines along ventromedial margin; palp article 3 as long as wide, rounded apically, dorsal surface with a transverse row of 2-3 imbricated and 4-5 sheathed spines along base of article 4; tip of palp article 4 slightly projected beyond article 3 , with several apical spines; margin and surface of each palp article with blunt spines on dorsal side, but with imbricated spines on ventral side.

Gnathopod 1 (Fig. 2E, G, J): carpus with narrow tumescent hump on posterodistal angle; propod ca. 0.6 times as long as carpus, with a row of evenly spaced 5-6 sheathed spines along base of tumescent hump and 1-2 bifid spines posterior margin, with 8-9 bifid spines on lateral surface, with 12-13 sheathed spines on medial surface, palmar margin weakly concave, posterior end of palm with 2 bifid spines on medial side, with a group of 4 imbricated spines on lateral side; dactyl lacking denticle, exceeding posterodistal angle of propod. Gnathopod 2 (Fig. 2K): coxal plate as wide as deep, posterior cusp obtuse; anterior margin of basis straight, posterior one weakly curved, both margins with minute spines; propod elliptic, posterior margin with 3-5 spines, palm with two dome-shaped protuberances, anterior one larger than posterior one, notch situated in middle of palm; dactyl tip slightly exceeding palm.

Pereopod 3 (Fig. 3E, N): coxal plate as wide as deep; carpus ca. 2.5 times as long as wide; propod ca. 1.2 times as long as carpus. Pereopod 4 (Fig. 3D, M) ca. 0.8 times as long as pereopod 3; coxal plate wider than deep, ventral margin straight; carpus 1.5-1.7 times as long as wide; propod ca. 1.4 times as long as carpus; dactyl base strongly pinched. Pereopod 5 (Fig. 3C, I, L) ca. 0.9 times as long as pereopod 3; anterior lobe of coxal plate broader (ca. 2.0 times) and deeper (ca. 1.4 times) than posterior lobe, ventral margin rounded, spinose; basis rounded, as deep as wide, posterodistal lobe shallow; merus as long as carpus; propod ca. 1.2 times as long as carpus. Pereopods 6 and 7 : merus to propod increasing in length distally; propod ca. 1.2 times as long as carpus, with 2 groups of 2 spines distally. Pereopod 6 (Fig. 3B, H, K) ca. 1.5 times as long as pereopod 3; anterodistal corner of posterior lobe of coxal plate right-angled or weakly projected ventrally; basis long elliptic; carpus not incrassate. Pereopod 7 (Fig. 3A, G, J) ca. 1.6 times as long as pereopod 3; coxal plate shallow, ventral margin with a few serrations; basis subcircular, medial surface with a longitudinal row of about 10 minute spines along axis; carpus thick, rectangular in lateral view, longer than that of pereopod 6 .

Coxal gill of gnathopod 2 narrow, belt-shaped, wavy. Coxal gills of pereopods 3 and 4 sac-like, distal half narrow. Coxal gill of pereopod 5 sac-like, distal half rounded. Coxal gill of pereopod 6 largest, proximal half folding, distal half leaf-shaped.

Abdominal side plates (Fig. 201-3): anterodistal corner and ventral margins bare, posterior margins weakly convex, weakly serrated, with several minute spines, posterodistal angle slightly projected posteriorly, ventral margin of side plate 1 smoothly rounded to posterior angle, anterodistal corners of side plates $2-3$ rounded.

Pleopods, with a small downward spine (Fig. 2T) on distolateral angle of peduncles, occasionally pleopod 3 lacking that, with 2 retinaculae (Fig. 2S). Peduncle of pleopod 1 (Fig. 2P) subequal to that of pleopod 2 in length, with a few spines proximally. Peduncle of pleopod 2 (Fig. 2Q) with several marginal spines. Peduncle of pleopod 3 (Fig. 2R) slightly shorter than those of pleopods 1 and 2, with spines on surface and margin; rami ca. 0.8 times as long as peduncles, inner rami subequal to or slightly longer than outer ones, 9-10-articulated, outer rami 10-11-articulated.

Uropod 1 (Fig. 2V): peduncle with 2 rows of marginal spines, with short distolateral spine; outer ramus ca. 0.8 times as long as peduncle, marginally bare, inner ramus with 4-5 spines on medial and lateral margins respectively, both rami with 2 long and 1-2 short spines distally. Uropod 2 (Fig. $2 \mathrm{~W}$ ) ca. 0.6 times as long as uropod 1; rami subequal to peduncle in length, inner ramus with 3 spines on medial and lateral margin respectively, outer ramus with 2 spines on lateral margin, both rami with 2 long and 1 short spines distally. Uropod 3 (Fig. $2 \mathrm{X}, \mathrm{Y}$ ) ca. 0.3 times as long as uropod 1; peduncle 

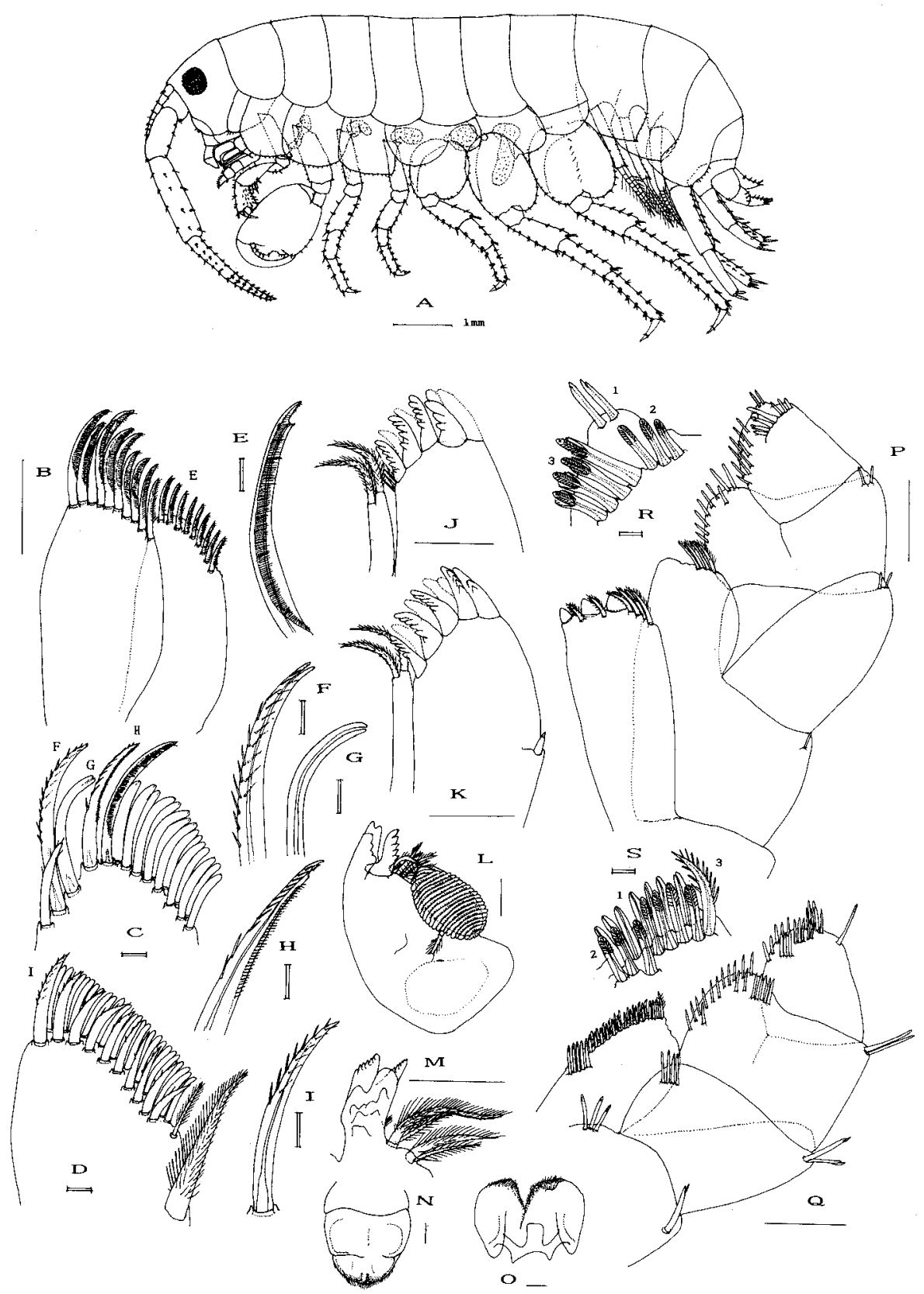

Fig. 1 Platorchestia joi Stock \& Biernbaum from Demao. Male, 9mm: A, lateral view; B ventral side of maxilla 2; C and D, dorsal side of outer and inner plate of maxilla 2; E, brush sharp spine; F, setulose sharp spine of outer plate; $G$, blunt spine; $H$, setulose sharp spine (with dense hair) of outer plate; I, setulose sharp spine of inner plate; $\mathrm{J}$ and $\mathrm{K}$, dorsal and ventral surfaces of maxilla 1 ; $\mathrm{L}$, left mandible; $\mathrm{M}$, lacinia mobilis of right mandible; $\mathrm{N}$, upper lip; $\mathrm{O}$, lower lip; $\mathrm{P}$ and $\mathrm{Q}$, dorsal and ventral surfaces of maxilliped; $R$, a row of setae of palp article 3 of maxilliped ( $R 1$, blunt spine; R2, imbricated spine; R3, sheathed spine); S, spines on inner lobe of outer plate of maxilliped ( $\mathrm{S} 1$, blunt spine; $\mathrm{S} 2$, imbricated spine; $\mathrm{S} 3$, pappose spine). Bar scales $0.1 \mathrm{~mm}$, double bar scales $0.01 \mathrm{~mm}$. 


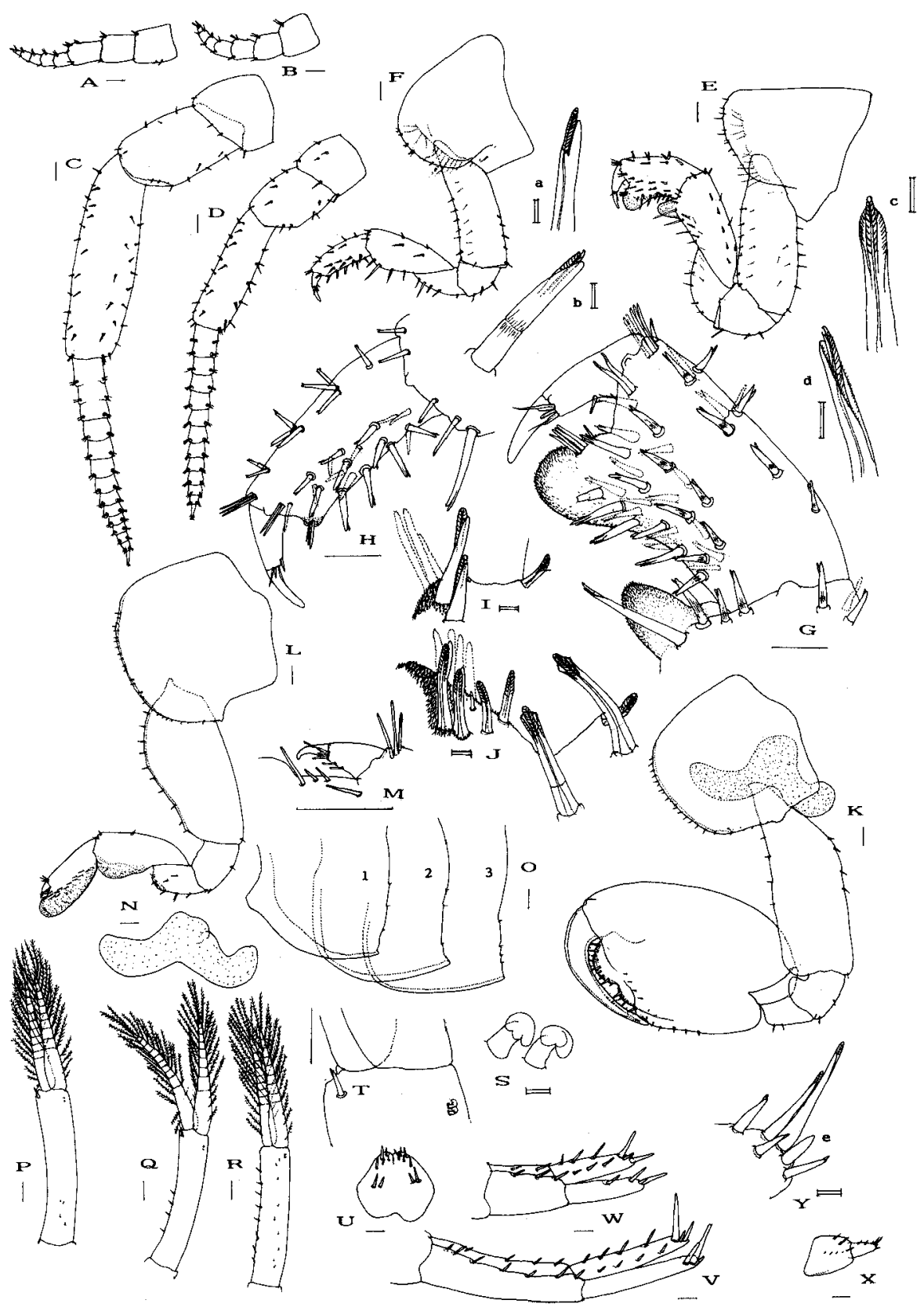

Fig. 2 Platorchestia joi Stock \& Biernbaum, from Demao. Male $9 \mathrm{~mm}$ and female $8 \mathrm{~mm}$ : A and B, male and female antennae $1 ; C$ and $D$, male and female antennae 2; E and F, male and female gnathopod 1; $\mathrm{G}$ and $\mathrm{H}$, propod and dactyl of male and female gnathopod 1 ; I and $\mathrm{J}$, posterior end of palm of female and male gnathopod 1 (medial side); $\mathrm{K}$ and $\mathrm{L}$, male and female gnathopod $2 ; \mathrm{M}$, dactyl of female gnathopod $2 ; \mathrm{N}$, coxal gill of female gnathopod 2; O1-O3, abdominal side plates 1-3; P-R, pleopods $1-3 ; \mathrm{S}$, retinaculae of pleopods; T, downward spine of pleopod $2 ; \mathrm{U}$, telson; $\mathrm{V}-\mathrm{X}$, uropods 1-3; Y, distal part of ramus of uropod 3; $a$ and $b$, bifid spine of female gnathopod 1; $c$ and $d$, sheathed spine of male gnathopod 1; e, smooth spine. Bar scales $0.1 \mathrm{~mm}$, double bar scales 0.01 $\mathrm{mm}$. Figures are of males if not mentioned. 


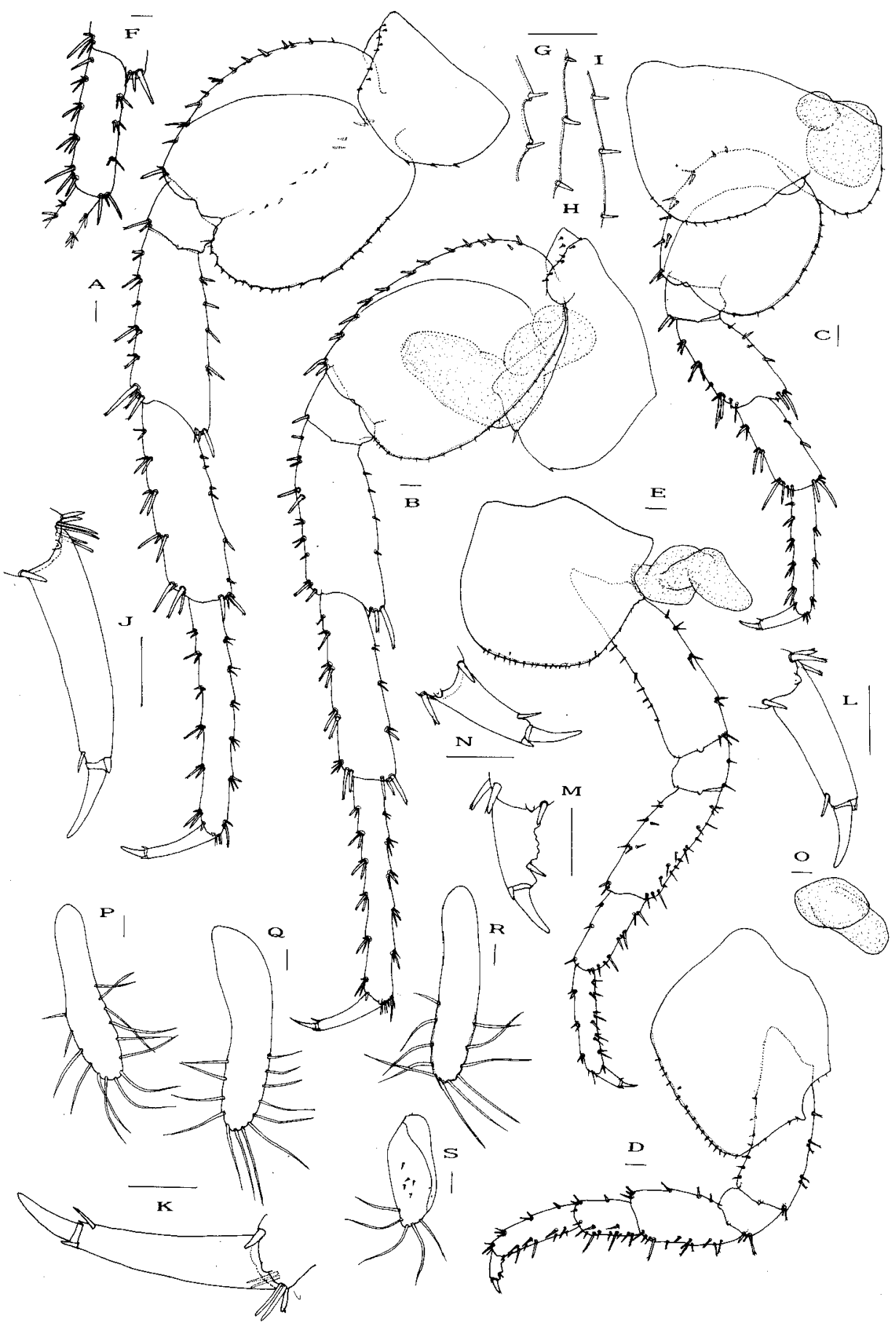

Fig. 3 Platorchestia joi Stock \& Biernbaum from Demao. Male $9 \mathrm{~mm}$ and female $8 \mathrm{~mm}$ : A-E, male pereopods $7-3 ; \mathrm{F}$, carpus of female pereopod $7 ; \mathrm{G}-\mathrm{I}$, posteromarginal spines of basis of pereopods $7-5 ; \mathrm{J}-\mathrm{N}$, dactyls of male pereopods $7-3 ; \mathrm{O}$, coxal gill of pereopod $4 ; \mathrm{P}$, brood plate of gnathopod 2; Q-S, brood plates of pereopods 3-5. Bar scales $0.1 \mathrm{~mm}$. Figures are of male if not mentioned. 
longer than wide, with 3-4 spines distally; ramus ca. 0.8 times as long as peduncle, with a few spines marginally, with 3 bifid spines subapically and with a group of 1 smooth spine and 2 bifid spines (unequal length) apically.

Telson (Fig. 2U) spade shaped, with a group of 3 spines apically and 3 groups of 1 or 2 spines dorsally.

Female

Body length 8-11 mm. Antenna 1 (Fig. 2B): flagellum ca. 0.6 times as long as peduncle, 4articulated. Antenna 2 (Fig. 2D): peduncular article 5 ca. 1.8 times as long as article 4, not incrassate; flagellum ca. 1.6 times as long as peduncular article 5, 11-13-articulated.

Gnathopod 1 (Fig. 2F, H, I): propod ca. 0.7 times as long as carpus, with 3 transversal rows of 3 bifid spines on lateral surface, with 3 bifid spines on posteromedial margin and 7-8 sheathed spines on medial surface, posterodistal corner weakly bulged, with a group of 4 imbricated spines on lateral side, with 2 bifid spines on medial side, palm very short, without marginal spines; dactyl lacking denticle, dactyl base with 1 stiff spine on posterodistal angle. Gnathopod 2 (Fig. 2 L, M): coxal plate as deep as wide, posterior cusp acute; anterior margin of basis evenly spinose; merus slightly longer than ischium, posterodistal corner tumescent, with spines; carpus with a few spines along base of shallow tumescence; propod tumescent posterodistally; dactyl base with 2 stiff spines on grasping margin.

Pereopod 7 (Fig. 3 F): carpus not incrassate.

Brood plates of gnathopod 2 (Fig. 3Q), pereopods 3 (Fig. 3P) and 4 (Fig. 3R) sublinear, each plate with 11-13 simple tipped setae on distal half margin. Brood plate of pereopod 5 (Fig. 3S) shortest, with several minute spines on surface and a few spines on posterior submargin, with 5 simple tipped setae distally.

\section{Remarks}

The material (body length 8-11 mm) from Taiwan well accords with the original description of $P$. joi (= P. crassicornis, body length $9-14 \mathrm{~mm}$ ) from the Russian coast of the Japan Sea given by Derzhavin (1937), but show following differences: the palm of male gnathopod 2 with shallow and narrow notch, the posterior protuberance lower and narrower than the anterior one (vs. the notch is deep and wide, the shape of the posterior protuberance is similar to the anterior one). Taiwanese specimens also show following differences from the Korean material (male, $12.5 \mathrm{~mm}$ ) redescribed by Jo (1988): 1) the flagellum of male antenna 2 is longer than the peduncular articles 5 (vs. shorter than the article 5); 2) the lacinia mobilis of left mandible 5-dentate (vs. 5- or 6-dentate); 3) the posterior margin of basis of pereopod 5 gently curved (vs. the posterior margin weakly concaved); 4) the peduncle of pleopod 3 occasionally lacking a downward spine (vs. usually with the spine).

Bousfield (1982) identified the species reported under the name of $P$. platensis by Bulycheva, (1957) and Morino, (1975) as $P$. joi (= P. crassicornis (Derzhavin, 1937)). Thereafter, Jo (1988) confirmed the Bousfield's notation as the results of his study on the genus Platorchestia from Korea and concluded that $P$. platensis reported by Iwasa (1939), Stephensen (1945), Gurjanova (1951), Kim $\&$ Kim (1987) were also $P$. joi. However we recognized several differences between $P$. joi and $P$. platensis by Morino (1975), namely, the latter has the peduncles of pleopods without downward spine on the outer distal angle, the propod of male gnathopod 2 without spines on posterior margin, the coxal plate of male gnathopod 2 with acute posterior cusp and carpus on male pereopod 7 incrassate. Meanwhile the figures of $P$. platensis by Iwasa (1939) exhibit features of $P$. joi: the dactyl of male gnathopod 1 is strong; the propod of male gnathopod 2 with spines on the posterior margin; the propod of pereopod 3 longer than the carpus; the carpus of pereopod 7 rectangular in lateral view. Therefore, the Platorchestia of from Birō, Hokkaido, Japan described by Iwasa (1939) is identified with $P$. joi and those of Morino (1975) are described below as a new species. The species of Stephensen (1945), Gurjanova (1951), Bulycheva (1957) and Kim \& Kim (1987) could not be identified by figures and descriptions of these authors. 


\section{Distribution in Taiwan}

This species was found on sandy shores and the riversides near the mouth of rivers of the north coast in the mainland (Demao, Fulung) (Fig. 15).

\section{Platorchestia pacifica n. sp.}

(Figs. 4-7, 15)

Orchestia platensis; non Krøyer, 1845: Chilton, 1921, pp. 538-541. fig. 7; Morino, 1975, pp. 172-175, figs. 1-3; Morino, 1999, p. 65, figs. 206, 212-2.

Platorchestia platensis: Morino \& Ortal, 1995, pp. 829-831.

\section{Material examined}

Four males and seven females ( 2 ovig.) from Chinshan, 4 Aug. 1976; five males and 27 females (five ovig.) from Yehliuchia, 10 Aug. 1981; 32 males and 12 females (9 ovig.) from Hualien, 3 Aug. 1976; two males and two females from Taitung, 2 Aug. 1976; five males and 12 females from Haikou, 3 Aug. 1979; 17 males and 12 females from Fengchiang, 8 Aug. 1979; nine males and 23 females (eight ovig.) from Fengchiang, 8 Aug. 1981; nine males and 23 females (eight ovig.) from Fangliao, 11 Aug. 1981; 22 males and 28 females (10 ovig.) from Anping, 15 Aug. 1981; two males and one females from Luchiang, 30 Jul. 1976; one male from Tunghsiao, 30 Jul. 1976; 18 males and 40 females (10 ovig.) from Nanliao, 7 Aug. 1981; seven males and six females ( 2 ovig.) from Yehyu, 29 Jul. 1981; four males and 18 females (three ovig.) from Neian, 13 Aug. 1981; 39 males and 34 females from Makung, 13 Aug. 1981.

Holotype: Male $10 \mathrm{~mm}$ (NMNS-IN-3449-001) from Anping, 15 Aug. 1981.

Paratypes: Allotype, female $8 \mathrm{~mm}$ (NMNS-IN-3449-002) from the same locality as holotype; other types: 2 え 2 우 우 (NMNS-IN-3449-1 to 4).

\section{Description of male (holotype)}

Since this species has many similarities to the previous one, only the different or important characters will be described below.

Body length $10 \mathrm{~mm}$. Eyes oblong. Antenna 1 (Fig. 5B), flagellum ca. 0.6 times as long as peduncle, 5-articulated. Antenna 2 (Fig. 5D) ca. 1/3 times as long as body length; peduncular articles 4 and 5 incrassate, peduncular article $5 \mathrm{ca} .1 .4$ times as long as article 4 ; flagellum ca. 1.3 times as long as peduncular article 5, decreasing distally in size, 4 proximal articles coalesced, 14-articulated.

Maxilla 1 (Fig. 4L, M): dentition formula 2-2-4-4-3-4-5-4-5. Maxilla 2 (Fig. 4J, K): inner plate with ca. 30 blunt spines on distal margin and a row of 11 setulose sharp spines on dorsal margin, a row of 10 brush sharp spines on ventral margin; outer plate with ca. 20 blunt spines on distal margin, a row of ca. 13 brush sharp spines on ventral margin and 2 setulose sharp spines on dorsal margin. Maxilliped (Fig. 4B, C, D, E): lobe of outer plate shorter than basal height, with 5 pappose spines on dorsal margin, inner distal corner right angled; palp article 3 as log as wide, rounded apically, dorsal surface with a curved row of 3 imbricated and 5 sheathed spines along base of palp article 4 , ventral surface with several imbricated spines along inner margin; tip of palp article 4 slightly projected beyond palp article 3 .

Gnathopod 1 (Fig. 5E, G, J): posterior margin of basis with 2 spines in middle, anterior margin straight, with many spines; tumescent hump of carpus conical; propod ca. 0.6 times as long as carpus, lateral side with 7 sheathed spines (distal 5 spines narrowly, proximal 2 spines widely spaced) along base of tumescent hump and with 2 bifid spines and 2 sheathed spine on surface, medial side with 13 sheathed spines, posterior end of palm with a group of 4 imbricated spines on lateral side and with a group of 2 bifid spines on medial side; dactyl with small denticle, tip of nail not exceeding posterodistal angle of propod. Gnathopod 2 (Fig. 5K): coxal plate as wide as deep, posterior cusp triangular; posterior margin of propod without marginal spines, palm shorter than posterior margin, 


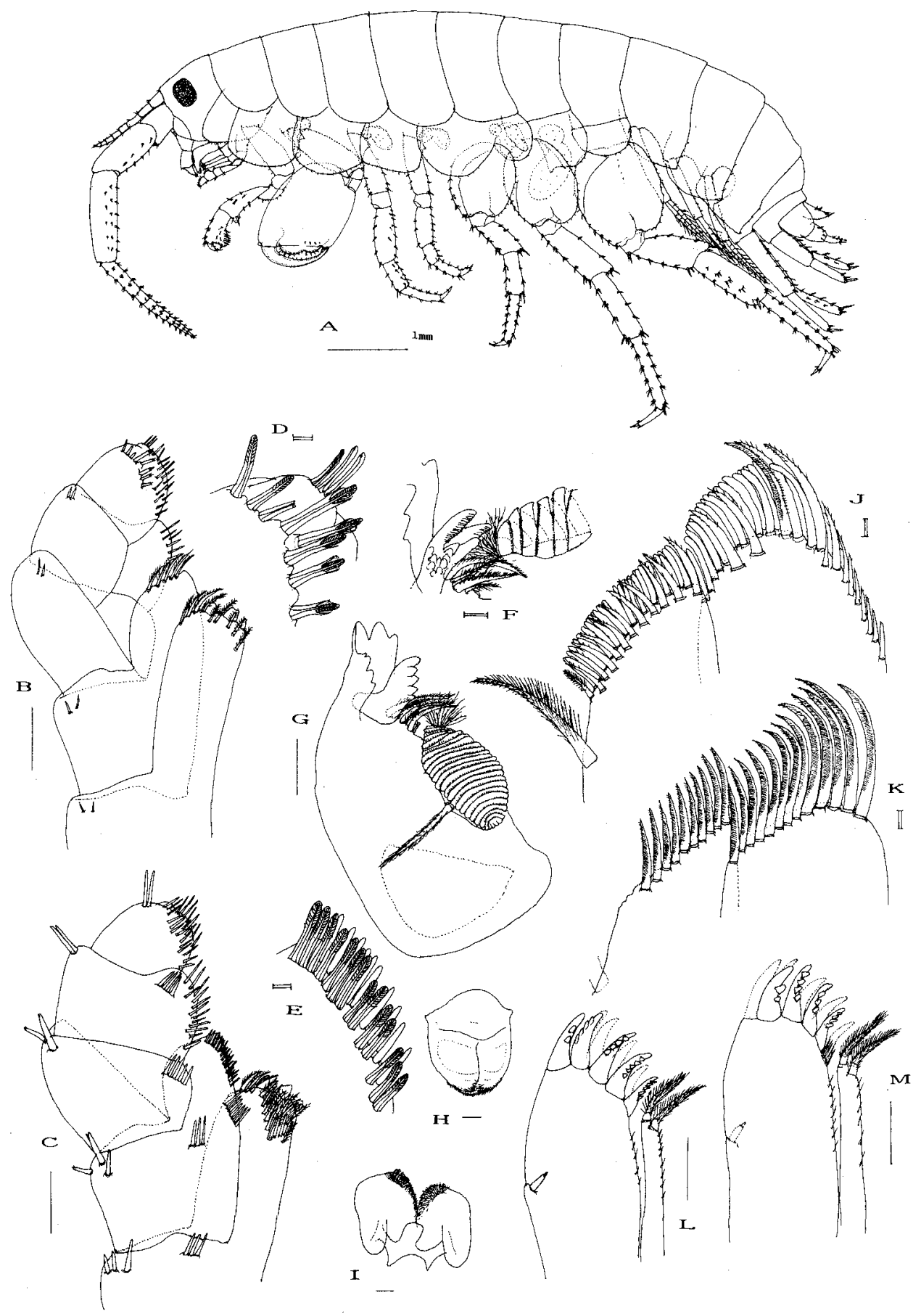

Fig. 4 Platorchestia pacifica $n$. sp. from Anping. Holotype male $10 \mathrm{~mm}$ : A. lateral view; B and C, dorsal and ventral surfaces of maxilliped; D, a row of spines of palp article 3 of maxilliped; $E$, spines on inner lobe of outer plate of maxilliped; F, lacinia mobilis of right mandible; $G$, left mandible; $H$, upper lip; I, lower lip; $\mathrm{J}$ and $\mathrm{K}$, dorsal side and ventral sides of maxilla 2; $\mathrm{L}$ and $\mathrm{M}$, ventral and dorsal surfaces of maxilla 1 . Bar scales $0.1 \mathrm{~mm}$, double bar scales $0.01 \mathrm{~mm}$. 
with two low protuberances, notch is located at about $3 / 5$ length from hinge of dactyl; dactyl strongly curved, distal part narrowed.

Pereopods 3 and 4: coxal plate as wide as deep; merus slightly broadening distally. Pereopod 3 (Fig. 6E, K): carpus ca. 2.5 times as long as wide; propod subequal to carpus in length. Pereopod 4 (Fig. 6D, J) ca. 0.8 times as long as pereopod 3; ventral margin of coxal plate straight; carpus ca. 1.7 times as long as wide; propod ca. 1.2 times as long as carpus; dactyl base weakly pinched. Pereopods 5-7: distal width of merus 1.5-1.6 times as long as proximal one. Pereopod 5 (Fig. 6C, I, N) ca. 0.9 times as long as pereopod 3; anterior lobe of coxal plate broader (ca. 1.8 times) and deeper (ca. 1.5 times) than posterior lobe, ventral margin strongly curved, spinose; basis oblong; propod ca. 1.1 times as long as carpus. Pereopods 6 and 7: propod with 2 groups of 4 spines distally. Pereopod 6 (Fig. 6B, $\mathrm{H}, \mathrm{M})$ ca. 1.5 times as long as pereopod 3; posterior lobe of coxal plate slightly deeper than wide, anterior corner projected ventrally, posterior corner rounded, spinose; basis elliptic; carpus weakly incrassate; propod ca. 1.2 times as long as carpus. Pereopod 7 (Fig. 6A, G, L) slightly longer than pereopod 6; basis subcircular, medial surface with a longitudinal row of several spines along axis; carpus strongly incrassate, oblong in lateral view; propod ca. 1.1 times as long as carpus.

Coxal gill of gnathopod 2 narrow, wavy. Coxal gills of pereopods 3 and 4 sac-like constricted in middle. Coxal gill of pereopod 5 sac-like, distal part rounded. Coxal gill of pereopod 6 largest twisted in middle, distal part leaf shaped.

Abdominal side plates (Fig. 5N1, 2, 3): posterior margin serrated, with minute spines, posterodistal angle slightly protruded, plate 3 rectangular in shape.

Pleopods (Fig. 5O, P, Q) without downward spine, peduncle of pleopod 1 with a few spines on surface, peduncle of pleopod 2 as long as that of pleopod 1, with several spines in middle part of outer margin, peduncle of pleopod 3 slightly shorter than those of pleopods 1 and 2, with spines all along outer margin and surface; rami ca. 0.7 times as long as peduncles, inner rami subequal to outer ones in length, 9-10-articulated, outer rami 10-11-articulated.

Uropod 1 (Fig. 5S): peduncle with short distolateral spine; rami ca. 0.7 times as long as peduncle, outer ramus marginally bare, inner ramus with 4 spines on inner margin and 3 spines on outer margin. Uropod 2 (Fig. 5T): rami ca. 0.8 times as long as peduncle, outer ramus with 1 spine on outer margin, inner ramus with 2 spines on both inner and outer margins. Uropod 3 (Fig. $5 \mathrm{U}, \mathrm{V}$ ): peduncle longer than deep, with 4 spines laterally; ramus ca. 0.6 times as long as peduncle, with 3 spines on dorsal margin, with 2 bifid spines subapically and with a group of 2 long bifid spines of unequal length and 1 short smooth spine apically.

Telson (Fig. 5W) with a group of apical spines and 2 groups of 2 dorsal spines on each lobe.

\section{Female (allotype)}

Body length $8 \mathrm{~mm}$. Antenna 1 (Fig. 5A) reaching end of peduncular article 4 of antenna 2: flagellum 5-articulated. Antenna 2 (Fig. 5C) not incrassate: peduncular article 5 ca. 1.5 times as long as article 4, slender; flagellum ca. 1.8 times as long as peduncular article 5, 15-articulated.

Gnathopod 1 (Fig. 5F, H, I): basis parallel sided; propod with 3 bifid spines marginally and 3 bifid spines submarginally on lateral side, with 3 bifid spines on posterior margin and 7 sheathed spines submarginally on medial side, posterodistal bulge with a group of 4 imbricated spines on lateral side and with 2 bifid spines on medial side, palm very short, without marginal spines; dactyl with denticle of small size, dactyl base with 2 stiff spines near posterodistal angle. Gnathopod 2 (Fig. 5L, M): coxal plate as deep as wide, ventral margin gently curved; basis expanded anteriorly; anterodistal corner of merus weakly tumescent; carpus ca. 2.0 times as long as merus; propod tumescent posterodistally; dactyl with 2 stiff spines on grasping margin.

Pereopod 7 (Fig. 6F): carpus not incrassate, rectangular in lateral view; propod ca. 1.2 times as long as carpus.

Brood plates of gnathopod 2 (Fig. 5L), pereopods 3 (Fig. 6 Q) and 4 (Fig. 6P) oblong, with 15-18 simple tipped setae marginally. Brood plate of pereopod 5 (Fig. 60) ca. 0.8 times as long as that of 


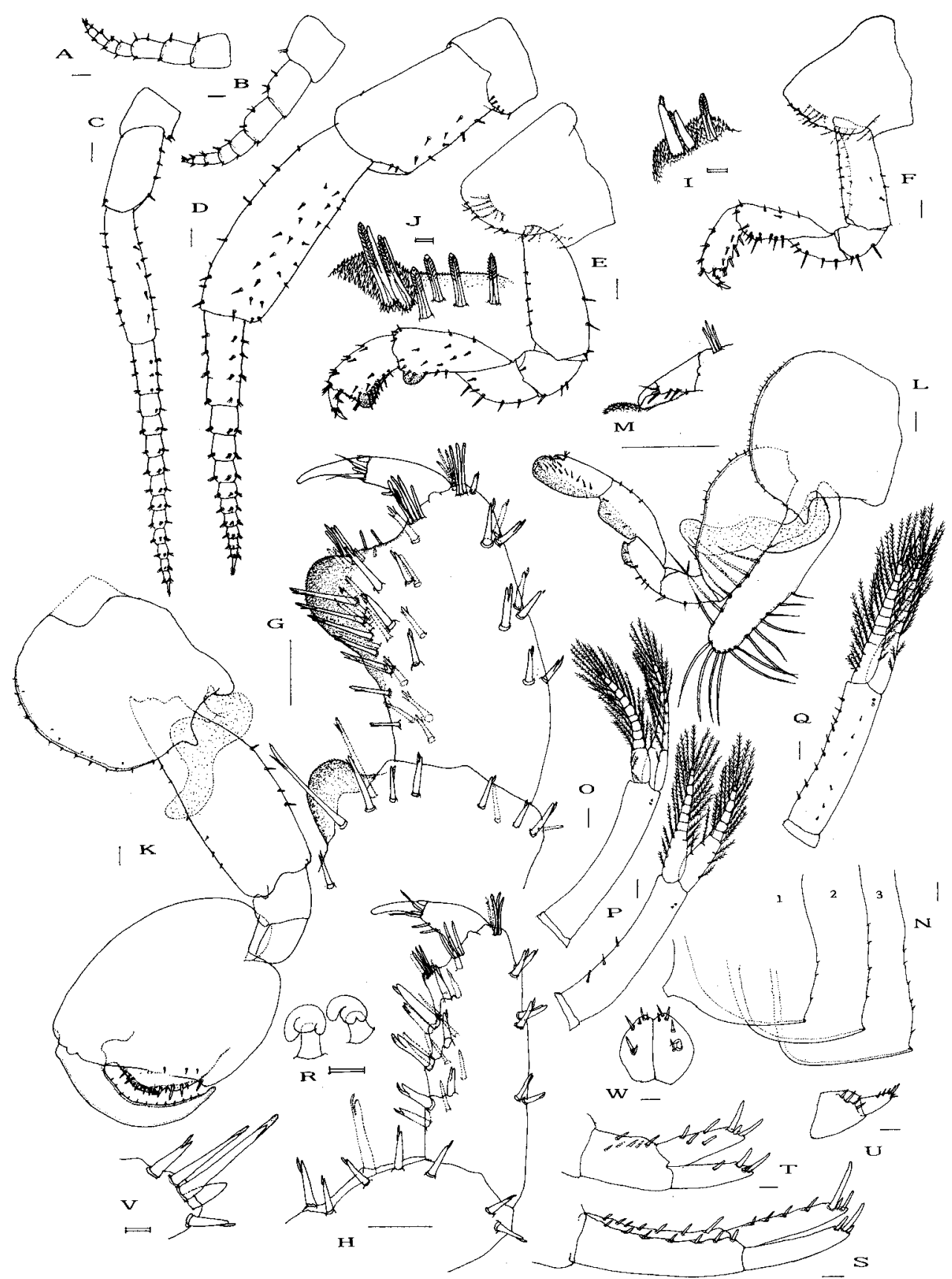

Fig. 5 Platorchestia pacifica n. sp. Male from Anping. Holotype male $10 \mathrm{~mm}$ and allotype female $8 \mathrm{~mm}$ : $A$ and $B$, female and male antennae $1 ; C$ and $D$, female and male antennae 2; $E$ and $F$, male and female gnathopods $1 ; \mathrm{G}$ and $\mathrm{H}$ dactyls and propods of male and female gnathopod $1 ; \mathrm{I}$ and $\mathbf{J}$, posterior end of palm of female and male gnathopod 1 (medial side); $\mathrm{K}$ and $\mathrm{L}$, male and female gnathopod 2; M, dactyl of female gnathopod 2; N1-N3, abdominal side plates 1-3; O-Q, pleopods $1-3$; R, retinaculae of pleopod $1 ; \mathrm{S}-\mathrm{U}$, uropods $1-3 ; \mathrm{V}$, distal part of ramus of uropod $3 ; \mathrm{W}$, telson. Bar scales $0.1 \mathrm{~mm}$, double bar scales $0.01 \mathrm{~mm}$. Figures are of male if not mentioned. 


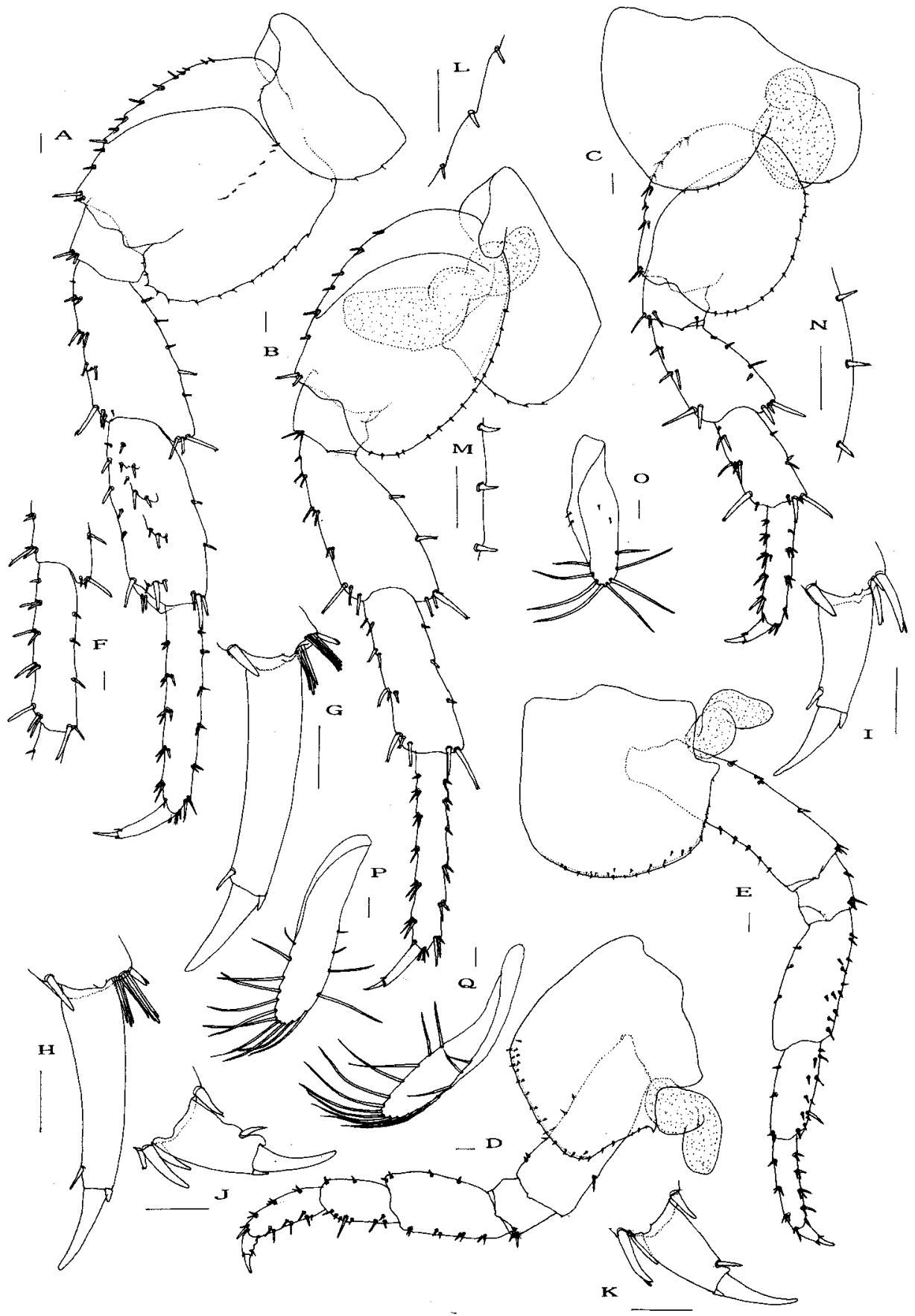

Fig. 6 Platorchestia pacifica n. sp. from Anping. Holotype male $10 \mathrm{~mm}$ and allotype $8 \mathrm{~mm}$ : A-E, male pereopods 7-3; F, carpus of female pereopod 7; G-K, dactyls of pereopods $7-3 ; \mathrm{L}-\mathrm{N}$, posteromarginal spines of basis of pereopods 7-5; O-Q, brood plates of pereopods 5-3. Bar scales $0.1 \mathrm{~mm}$. Figures are of males if not mentioned.ntioned. 


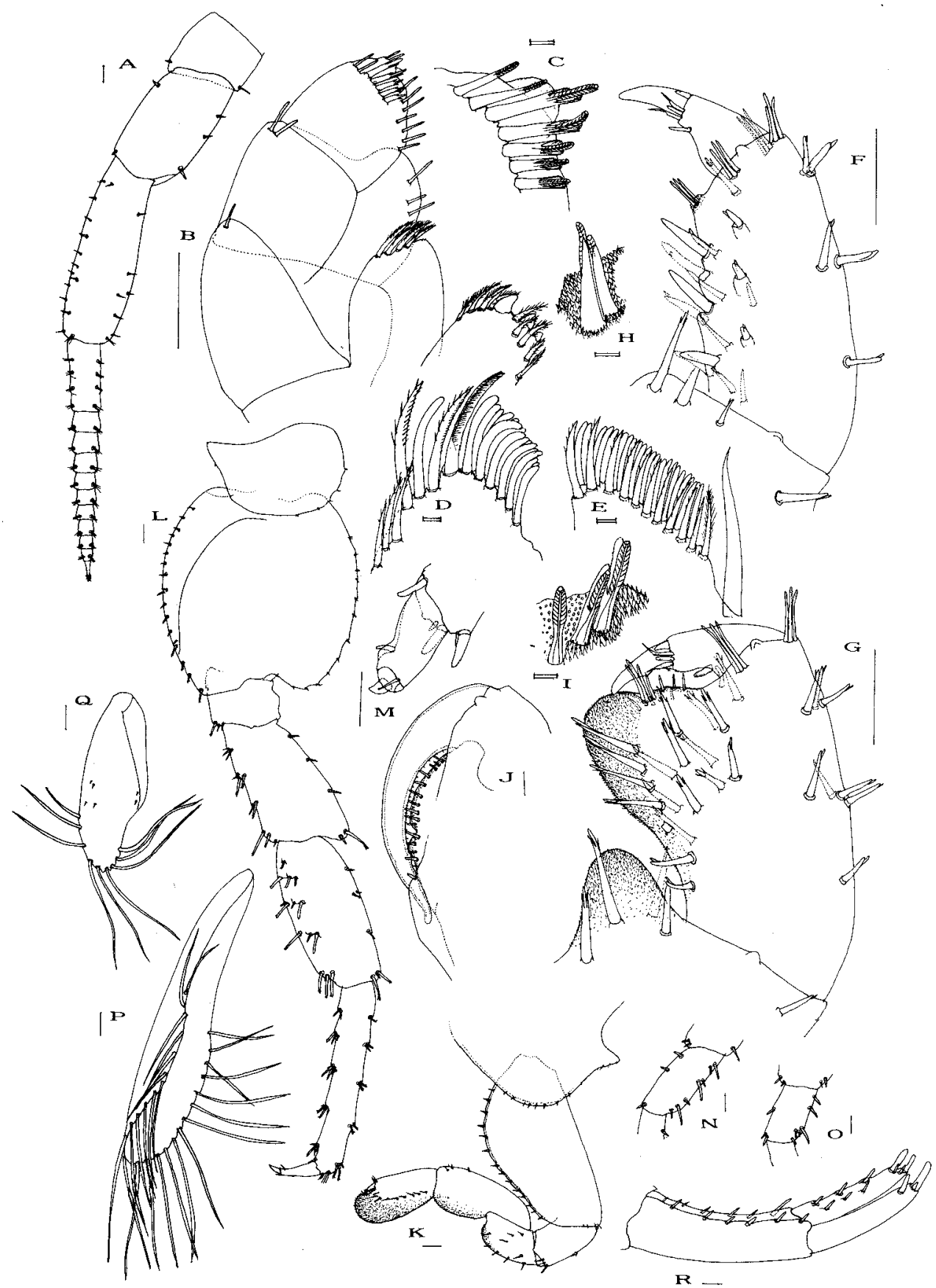

Fig. 7 Platorchestia platensis (Krøyer) from Kent, England, male $10 \mathrm{~mm}$ and female $12 \mathrm{~mm}$ : A, male antenna 2; B, dorsal surface of maxilliped; C, a row of distal spines of palp article 3 of maxilliped; $\mathrm{D}$ and $\mathrm{E}$, outer and inner plates of maxilla 2 (dorsal side); F and G, propods and dactyls of female and male gnathopod 1 (lateral side); $\mathrm{H}$ and $\mathrm{I}$, posterior end of palm of female and male gnathopod 1 (medial side); J, propod of male gnathopod 2; K, female gnathopod 2; L, male pereopod 7; M, dactyl of pereopod 4; $\mathrm{N}$ and $\mathrm{O}$, carpus of pereopods 3 and $4 ; \mathrm{P}$, brood plate of gnathopod 2; $\mathrm{Q}$, brood plate of pereopod 5; R, male uropod 1. Bar scales $0.1 \mathrm{~mm}$, double bar scales $0.01 \mathrm{~mm}$. Figures are of males if not mentioned. 
gnathopod 2, with 2 minute spines on anterior side and a few spines on surface, with 8 simple tipped setae on distal half margin.

\section{Remarks}

This new species is most closely allied to $P$. platensis, next to $P$. joi and $P$. munmui. The specimens of $P$. platensis from Kent, England (Fig. 7) and P. munmui from Daebon, Korea have been examined and compared with $P$. pacifica $\mathrm{n}$. sp.. Table 1 summarized the distinguished characters among these species. And the main diagnostic characters are shown in the key.

The authors consider " $P$. platensis" from India described by Chilton (1921) as $P$. pacifica. Because his figures of male antenna 2, gnathopods 1,2 and pereopod 7 show the following features of this new species: 1) the peduncular article 5 of antenna 2 ca. 1.4 times as long as the article 4 , flagellum ca. 1.2 times as long as the article 5 ; 2) the dactyl of gnathopod 1 almost reaching the posterodistal angle; 3) the palm of gnathopod 2 with 2 low protuberances, the trough between two situated at ca. $3 / 5$ from dactyl hinge; 4) the carpus of pereopod 7 did not strongly incrassate. The species of Morino \& Ortal (1995) from Israel and the Sinai show also the features of $P$. pacifica on male gnathopods 1 and 2, pereopod 7, though not for the shape of posterior lobe of coxal plate 6 . Moore (1986) described "Orchestia platensis" from Hong Kong. However, he did not describe the diagnostic characters of $P$. platensis nor $P$. pacifica. Myers (1985) described "Orchestia. platensis" from Fiji. His figures of male (body length $15 \mathrm{~mm}$ ) show the features of $P$. mondi on eyes and pereopod 7 .

\section{Distribution in Taiwan}

Platorchestia pacifica n. sp. was found from under vegetable detritus in almost all coasts including sandy and shingly shores of mainland (Demao, Chinshan, Yehliuchia, Fulung and Hualien.

Table 1. Character distribution among four species of Platorchestia

\begin{tabular}{|c|c|c|c|c|}
\hline Characters/species & P. pacifica n. sp. & P. platensis & P. munmui & P. joi \\
\hline Locality & Taiwan & England & Korea & Taiwan \\
\hline Ant. $2\left(\sigma^{\top}\right)$, relative length of ped. art. 5 to art. 4 & ca. 1.4 & ca. 1.4 & ca. 1.4 & ca. 1.9 \\
\hline Ant. $2\left(\sigma^{1}\right)$, relative length of flage. to ped. art. 5 & ca. 1.3 & ca. 1.4 & ca. 1.2 & ca. 1.1 \\
\hline Mx. 2, out, pl, dorsal setulose spines & present & absent & absent & absent \\
\hline Gn.1, denticle f dactyl & smaller or & $\begin{array}{c}\text { distinct } \\
\text { rudimentary }\end{array}$ & distinct & absent \\
\hline Gn. $1(\AA)$, propod lateral spination includes: & 2-3 bifid spines & $1-2$ bifid spines & 3 bifid spines & $8-9$ bifid spines \\
\hline Gn. 1 ( ( ), propod lateral spination includes: & 2 longit. rows & 2 longit. rows & 2 longit. rows & 3 longit. rows \\
\hline Gn. $2\left(\delta^{\AA}\right)$, propod posterior margin & bare & bare & bare & spinore \\
\hline Gn. $2(\succsim)$, palm protuberance & low & flat & low & high dome shaped \\
\hline Gn. $2(\partial)$, position of palm notch from dactyl hinge & ca. $3 / 5$ & ca. $2 / 3$ & ca. $2 / 3$ & ca. $1 / 2$ \\
\hline $\mathrm{Cx}_{2} 2\left(\sigma^{\pi}\right)$, posterior cusp & acute & acute & acute & obtuse \\
\hline Cx. 2-4 & as wide as deep & as wide as deep & wider than deep & as wide as deep \\
\hline Cx. 2 (우), posterior cusp, degree of prominence & weak & strong & strong & weak \\
\hline Per. 3 , relative length of propod to carpus & subequal & subequal & subequal & longer \\
\hline Per. 4, relative length of propod to carpus & ca. 1.7 & ca. 1.8 & ca. 1.4 & ca. 1.6 \\
\hline Per. $7\left(\sigma^{\star}\right)$, carpus incrassation & weak & strong & strong & very weak \\
\hline Per. $7\left(\delta^{\star}\right)$, carpus lateral view & oblong & elliptic & elliptic & rectangular \\
\hline Pl. 2-3, peduncle downward spines & absent & absent & absent & persent \\
\hline Pl. 2-3, peduncle outer margin & several spines & a few spines & several spines & many spines \\
\hline Up. 1, inner ramus, inner marginal spines & 4 & 3 & 3 & $4-5$ \\
\hline
\end{tabular}


Taitung, Haikou Fangliao, Fengchiang, Anping, Luchiang, Tunghsiao) and Lu-Tao (Nanliao), LanHsu (Yehyu), Peng Hu Lie-Tao (Makung, Neian). (Fig. 15).

Platorchestia japonica (Tattersall, 1922)

(Figs. 8-10, 15)

Orchestia japonica Tattersall 1922: pp. 452-453, PI. XXI, Figs. 1-10.

Platorchestia japonica: Bousfield, 1982, pp. 27; Morino \& Dai, 1990, pp. 21-26, figs. 9-11; Morino, 1999 , p. 65 , figs. $206,212-2$.

\section{Material examined}

Three males and two females from Tanshui, 6 Aug. 1979; three males and five females from Nanfan-ao, 31 Jul. 1981.

\section{Description of male}

Body length 7-8 mm. Eyes medium large, subround. Antenna 1 (Fig. 9A) reaching distal end of peduncular article 4 of antenna 2; articles of peduncle subequal to each other in length; flagellum 0.60.7 times as long as peduncle, 3-4-articulated. Antenna 2 (Fig. 9C) ca. 1/3 times as long as body length; peduncular article $5 \mathrm{ca} .1 .4$ times as long as article 4 , weakly incrassate; flagellum ca. 2.0 times as long as peduncular article 5,12-14-articulated, articles longer than wide, slightly decreasing distally in size, and with 4 groups of 3 spines.

Buccal mass ventral. Upper lip (Fig. 8I) deeper than wide. Lower lip (Fig. 8J) inner shoulder and margin of central trough pilose. Lacinia mobilis of left mandible (Fig. $8 \mathrm{H}$ ) 5 -dentate. Lacinia mobilis of right mandible (Fig. 8G) tricuspate. Maxilla 1 (Fig. 8B, C): dentition formula 2/3-2-4-5-5-5-5-4-4. Maxilla 2 (Fig. 8D, E, F): inner plate with $17-20$ blunt spines on distal margin, a row of $8-9$ setulose sharp spines on dorsal margin and a row of 8-9 brush sharp spines on ventral margin; outer plate, with 13-15 blunt spines on distal margin, a row of 11-12 brush sharp spines on ventral margin and 3 setulose sharp spines on dorsal margin. Maxilliped (Fig. 8K, L, M, N): lobe of outer plate shorter than basal height, with 4-5 pappose spines on dorsal margin, mediodistal corner truncated or rounded, with 2 rows of imbricated and blunt spines along ventromedial margin; palp article 3 as long as wide, rounded apically, proximal half of medial margin without spines, dorsal side with a row of 2 imbricated and 4 sheathed spines along base of palp article 4 , ventral side with several imbricated spines on mediodistal part; distal half of palp article 4 projected beyond article 3 , with a few spines apically.

Gnathopod 1 (Fig. 9F, H, J): anterodistal corner of coxal plate right-angled; propod ca. 0.7 times as long as carpus, tumescent posterodistally, lateral side with 5-6 sheathed spines along base of tumescent hump and with 2-3 sheathed spines on surface, medial side with 7-8 sheathed spines on surface; palmar margin weakly concaved, posterior end of palm with 4 imbricated spines on lateral side, with 2 bifid spines (occasionally 1 bifid spine) and 3-4 imbricated spines on medial side; dactyl without denticle, tip of nail not reaching posterodistal angle of propod. Gnathopod 2 (Fig. 9L): coxal plate as deep as wide, ventral margin weakly convex, posterior cusp acute; basis without anterior marginal spines, posterior margin with 4 spines in middle; propod oval, posterior margin weakly convex or almost straight, marginally bare, palm ca. 0.6 times as long as posterior margin, gently convex; distal part of dactyl narrowed.

Pereopods 3 and 4: coxal plate wider than deep, posterior cusp small. Pereopod 3 (Fig. 10E, N): ventral margin of coxal plate weakly convex; carpus ca. 2.3 times as long as wide; propod ca. 1.3 times as long as carpus. Pereopod 4 (Fig. 10D, M) ca. 0.9 times as long as pereopod 3; ventral margin of coxal plate straight; carpus ca. 2.2 times as long as wide; propod ca. 1.3 times as long as carpus; dactyl base weakly pinched. Pereopod 5 (Fig. 10C, L, I) subequal to pereopod 3 in length; anterior lobe of coxal plate much broader (ca. 2.0 times) and slightly deeper than posterior lobe (ca. 1.3 times), 

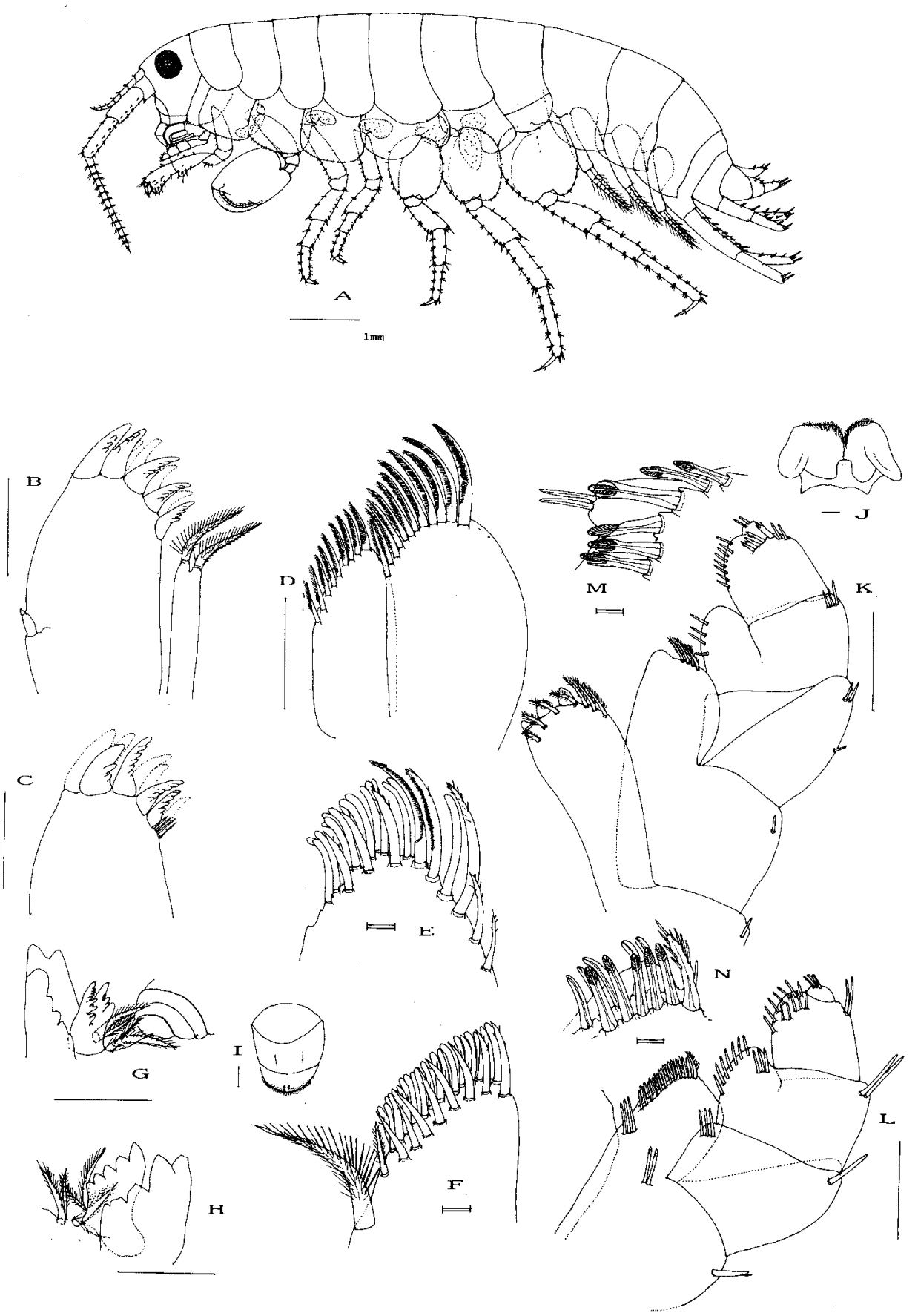

Fig. 8 Platorchestia japonica (Tattersall) from Nanfan-ao. Male $8 \mathrm{~mm}$ : A. lateral view; B and C, ventral and dorsal surfaces of maxilla $1 ; \mathrm{D}$, ventral side of maxilla $2 ; \mathrm{E}$ and $\mathrm{F}$, dorsal side of outer and inner plates of maxilla 2; $\mathrm{G}$ and $\mathrm{H}$, lacinia mobilis of right and left mandibles; I, upper lip; J, lower lip; $\mathrm{K}$ and $\mathrm{L}$, dorsal and ventral surfaces of maxilliped; $\mathrm{M}$, a row of distal spines of palp article 3 of maxilliped; $N$, spines of inner lobe of outer plate of maxilliped. Bar scales $0.1 \mathrm{~mm}$, double bar scales $0.01 \mathrm{~mm}$. 


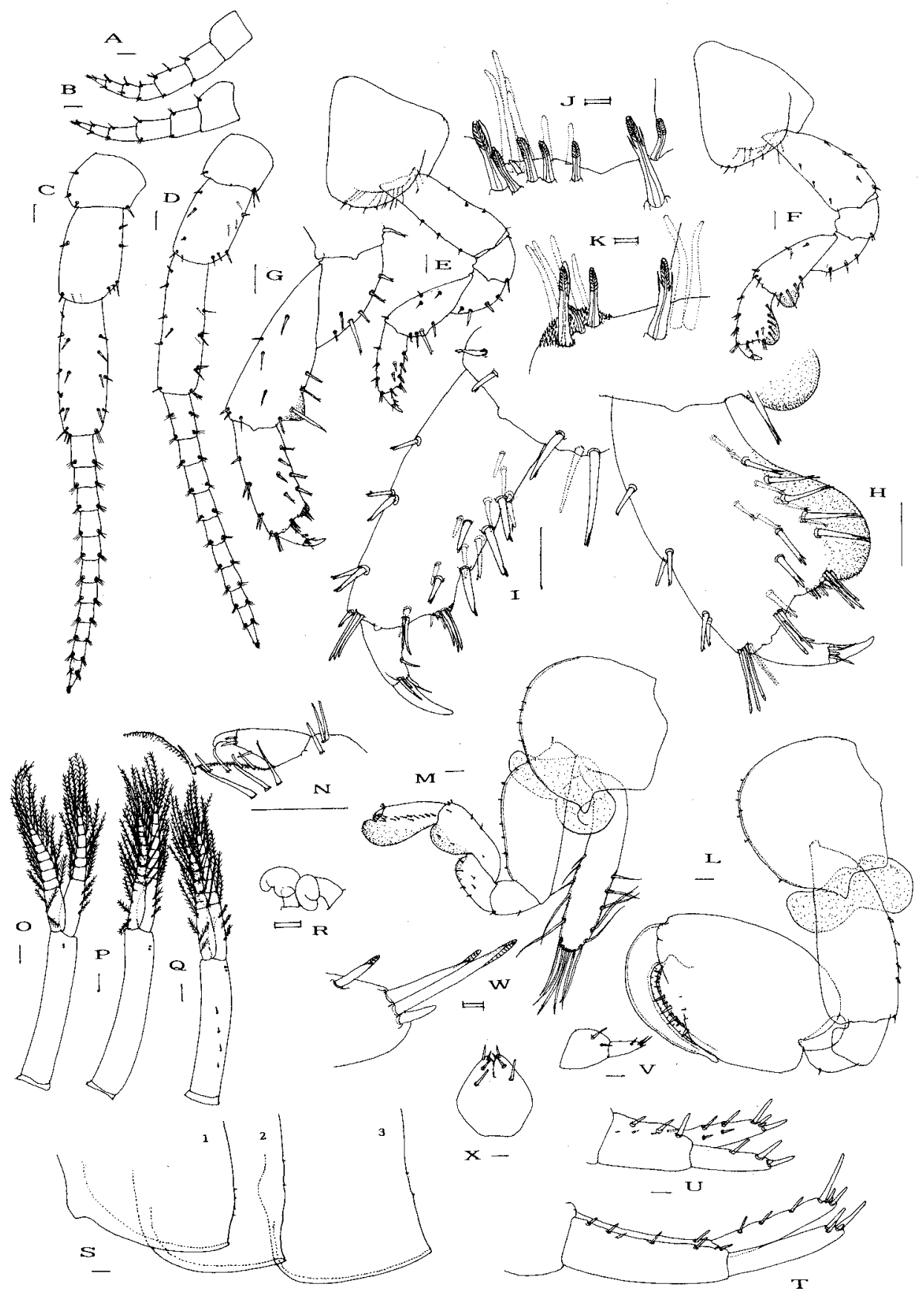

Fig. 9 Platorchestia japonica (Tattersall) from Nanfan-ao. Male $8 \mathrm{~mm}$ and female $8 \mathrm{~mm}$ : A and B, male and female antennae $1 ; \mathrm{C}$ and $\mathrm{D}$, male and female antennae $2 ; \mathrm{E}$ and $\mathrm{F}$, female and male gnathopod $1 ; \mathrm{G}$, variation of a female gnathopod $1 ; \mathbf{H}$ and $\mathbf{I}$, propods and dactyls of male and female gnathopod 1; $\mathrm{J}$ and $\mathrm{K}$, posterior end of palm of male and female gnathopod 1 (medial side); $\mathrm{L}$ and $\mathrm{M}$, male and female gnathopods 2 ; N, dactyl of female gnathopod 2; O-Q, pleopods 1-3; R, retinaculae of pleopod $1 ; \mathrm{S} 1-\mathrm{S} 3$, abdominal side plates $1-3 ; \mathrm{T}-\mathrm{V}$, uropods $1-3 ; \mathrm{W}$, distal part of ramus of uropod $3 ; \mathrm{X}$, telson. Bar scales $0.1 \mathrm{~mm}$, double bar scales $0.01 \mathrm{~mm}$. Figures are of males if not mentioned. 


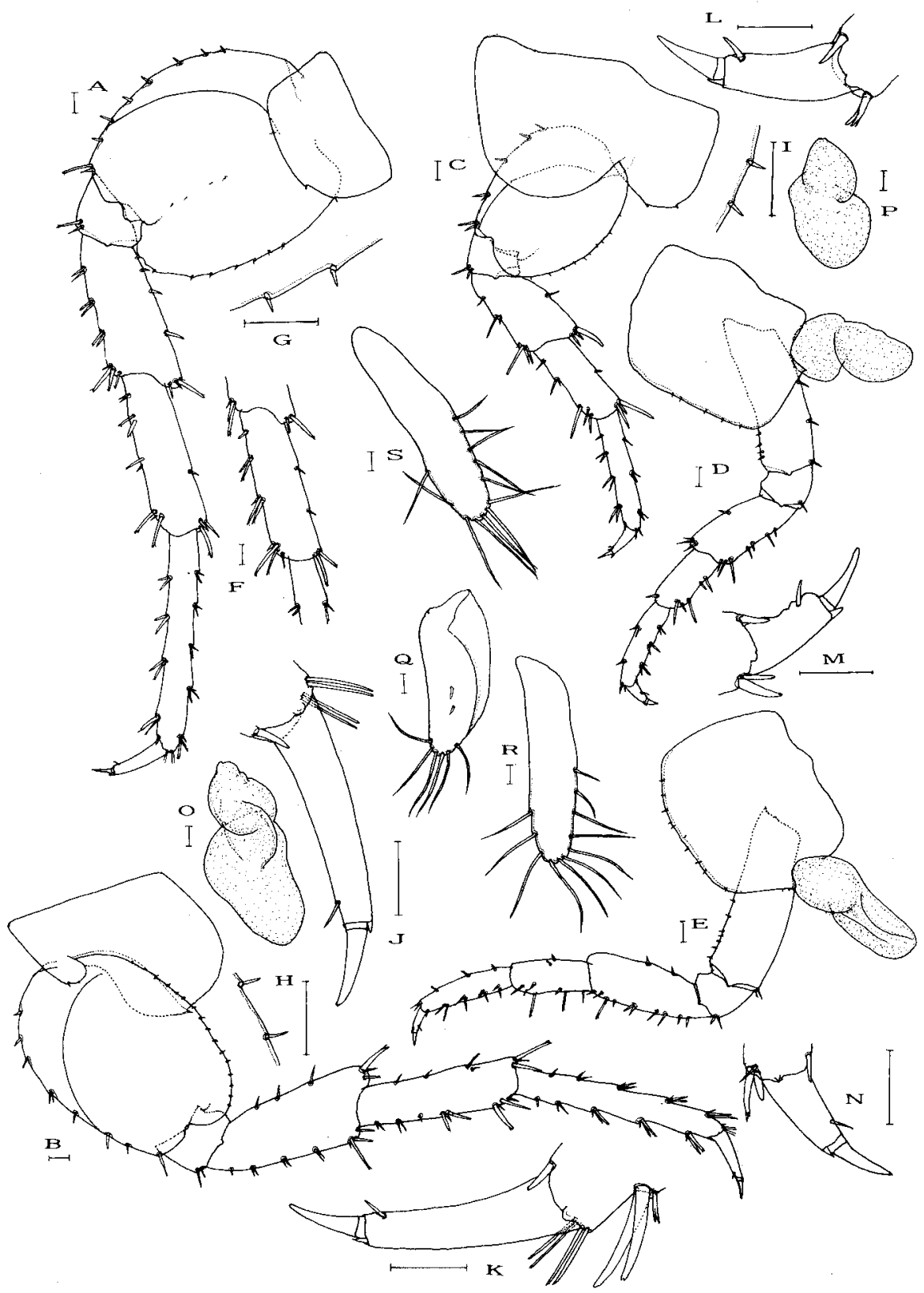

Fig. 10 Platorchestia japonica (Tattersall) from Nanfan-ao. Male $8 \mathrm{~mm}$ and female $8 \mathrm{~mm}$ : A-E, pereopods 7-3; F, carpus of female pereopod 7; G-I, posteromarginal spines of basis of pereopods $7-5$; J-N, dactyl of pereopods 7-3; O and P, coxal gills of pereopods 6 and 5 ; Q-S brood plates of pereopods 5-3. Bar scales $0.1 \mathrm{~mm}$. Figures are of male if not mentioned. 
ventral margin convex; basis oval; merus longer than carpus; propod ca. 1.2 times as long as carpus. Pereopods 6 and 7: propod ca. 1.3 times as long as carpus, with 2 groups of 2 spines distally. Pereopod 6 (Fig. 10B, H, K) ca. 1.5 times as long as pereopod 3; posterior lobe of coxal plate deeper than wide, anterodistal corner rounded; basis oblong, posterior margin weakly curved. Pereopod 7 (Fig. 10A, G, J) subequal to pereopod 6 in length; basis subcircular, posterior margin sparsely and shallowly serrated, with a longitudinal row of several minute spines along axis on medial surface; carpus slightly thicker than that of pereopod 6 , but not incrassate.

Coxal gill of gnathopod 2 broad and long, belt-shaped, wavy. Coxal gills of pereopods 3 and 4 sac-like, distal half narrow. Coxal gill of pereopod 5 (Fig. 10P) sac-like swelled. Coxal gill of pereopod 6 (Fig. 100) largest, proximal half folding, distal one leaf-shaped.

Abdominal side plates (Fig. 9S1, 2, 3): posterior margin weakly serrated, with minute spines, posterodistal angles weakly projected posteriorly.

Pleopods (Fig. 9O, P, Q) without downward spine on peduncles, peduncle of pleopod 2 slightly longer than that of pleopod 1, peduncle of pleopod 3 shortest, with several spines on surface and fine spines on lateral margin; rami $0.8-0.9$ times as long as peduncle, inner rami slightly longer than outer ones, 8-9-articulated, outer rami 9-10-articulated.

Uropod 1 (Fig. 9T): peduncle with short distolateral spines; rami ca. 0.7 times as long as peduncle, inner ramus with 3 spines on medial margin and without or with 1 spine on lateral margin. Uropod 2 (Fig. 9U): rami subequal to peduncle in length, outer ramus with 1 marginal spine, inner ramus with 2 spines on medial and lateral margins respectively. Uropod 3 (Fig. 9V, W): peduncle with 2 spines laterally; ramus shorter than peduncle, with 1 marginal spine, with a group of 2 long bifid spines (unequal length) and 1 short smooth spine apically.

Telson (Fig. 9X) subtriangular, apically notched, each lobe with a group of 2 spines on apex and 2 spines dorsally.

\section{Female}

Body length 6-8 mm. Antenna 1 (Fig. 9B): flagellum ca. 0.7 times as long as peduncle, 4articulated. Antenna 2 (Fig. 9D): peduncular article 5 slender, ca. 1.6 times as long as article 4; flagellum ca. 2.1 times as long as peduncular article 5, ca. 12-articulated.

Gnathopod 1 (Fig. 9E, I, K): basis parallel sided; propod ca. 0.6 times as long as carpus, with 3-4 bifid spines on posterolateral margin and 2-3 bifid spines on lateral surface, with 2-3 bifid spines on posteromedial margin and 6-7 sheathed spines on medial surface, posterodistal bulge with a group of 4 imbricated spines on lateral side and with 2 bifid spines (occasionally 1 bifid spines) on medial side, palm very short, oblique, without marginal spines; dactyl base lacking denticle, with 1 stiff spine in middle of grasping margin. Gnathopod 2 (Fig. 9M, N): posterodistal margin of coxal plate smoothly reached posterior cusp, cusp projected right angle posteriorly; anterior margin of basis spinose; merus subequal to ischium in length, posterodistal angle weakly tumescent, scabrous; propod 0.8-0.9 times as long as carpus; dactyl base with 1 stiff spine on grasping margin, nail very small, hooked.

Carpus of pereopod 7 (Fig. 10 F) not incrassate, rectangular in lateral view.

Brood plates of gnathopod 2 (Fig. 9M), pereopods 3 and 4 (Fig. 10S, R) long oval, reaching distal end of ischium, with 11-16 simple tipped setae on distal half margin. Brood plate of pereopod 5 (Fig. 10Q) subequal to basis in length, with 6 simple tipped setae apically, with a few spines on surface.

\section{Remarks}

Some female specimens from Nanfan-ao have the carpus and propod of gnathopod 1 with small tumescent hump on posterodistal angle (Fig. 9G). While others and those from Tanshui lack the humps (Fig. 9I).

The materials from Taiwan show the following difference from those of type locality (body length, male $12.5 \mathrm{~mm}$, female $12 \mathrm{~mm}$, Lake Biwa of Japan): 1) peduncular articles 4 and 5 of antenna 2 and carpus of pereopod 7 not sexual dimorphic (vs. those are more or less sexual dimorphic); 2) 
coxal plate of pereopod 6 , anterodistal corner of the posterior lobe is gently curved (vs. strongly curved); 3) peduncles of pleopods 2 and 3 without marginal spines (vs. with marginal spines); 4) pereopods 6 and 7 with 2 groups of 2 spines distally (vs. with 2 groups of 3 spines distally). The Taiwanese materials well accord with the description and the figures given by Morino \& Dai (1990) from Nanhu, Wuhan (China) except for the shape of the coxal plate of pereopod 6 and number of marginal spines of uropods 1-3.

Not fully mature stage of males and females of $P$. pacifica and $P$. joi bears much resemblance to those of $P$. japonica. However, in addition to the distingushing characters in the key, this species has the following characters that can distinguish from the former: 1) carpus of pereopod 5 longer than merus (vs. carpus subequal to merus in length); 2) the coxal gill of gnathopod 2 is broad and long (vs. narrow, short); 3) merus of female gnathopod 2 with low and round tumescent hump on posterodistal corner (vs. with angular tumescent hump posterodistally).

Platorchestia japonica is similar to P. ashmoleorum, described by Stock (1996) from St. Helena Island. However the former is distinguished from the latter in having the following features: 1) the flagellum of antenna $2 \mathrm{ca} .2 .0$ times as long as peduncular article 5 (vs. ca. 1.4 times); 2) palp article 2 of maxilliped with medial spines (vs. without medial spines); 3 ) carpus of female gnathopod 2 humped posteroproximally (vs. humped posteromedially, without constricted distal position); 4) the coxal plate of pereopod 7 subequal to proximal margin of basis in width (vs. much shorter than proximal margin and deep).

\section{Distribution in Taiwan}

$P$. japonica was found under fallen leaves and grass in humid places such as banks of streamlets and paddy fields of the north region in the mainland (Tanshui and Nanfan-ao) (Fig. 15).

\section{Platorchestia humicola (Martens, 1868)}

(Figs. 11-15)

Orchestia humicola Martens, 1868: pp. 56-57; M. Weber, 1892, pp. 569-570; Stebbing, 1906, p. 539. Platorchestia humicola: Morino, 1999, p. 65, figs. 206, 213-1.

\section{Material examined}

Sixteen females from Demao, 18 Aug. 1981; five females from Fulung, 7 Aug. 1979; two males and 10 females from Fulung, 30 Jul. 1981; 18 females from Tachi, 8 Aug. 1979; two males and nine females from Tachi, 31 Jul. 1981; one male and 21 females from Shuilien, 1 Aug. 1981.

\section{Description of female}

Body length $8-10 \mathrm{~mm}$. Eyes medium large, subcircular. Antenna 1 (Fig. 12A) reaching distal end of peduncular article 4 of antenna 2; flagellum ca. 0.7 times as long as peduncle, 4-articulated. Antenna 2 (Fig. 12C): peduncular article 5 ca. 1.5 times as long as article 4; flagellum ca. 2.0 times as long as peduncular article 5, 13-14-articulated.

Buccal mass slightly prognathous. Upper lip (Fig. 11H) deeper than wide. Lower lip (Fig. 11I): inner shoulder and margin of central trough pilose. Lacinia mobilis of left mandible (Fig. 11G): 5dentate. Lacinia mobilis of right mandible (Fig. 11F): tricuspate. Maxilla 1 (Fig. 11L, M): dentition formula 2-2-4-4-4-4-5-5-4. Maxilla 2 (Fig. 11J, K): inner plate with 18-20 blunt spines on distal margin, a row of ca. 10 setulose sharp spines on dorsal side and a row of 8-9 brush sharp spines on ventral margin; outer plate with 13-15 blunt spines and 4 spines on distal margin, with a row of 10-11 brush sharp spines on ventral margin and with 2-3 setulose sharp spines on dorsal margin. Maxilliped (Fig. 11B, C, D, E): lobe of outer plate slightly shorter than basal height, mediodistal corner rightangled, with 4 pappose spines on dorsodistal margin, with 2 rows of imbricated spines and blunt spines along ventromedial margin; dorsal side of palp article 3 with a row of 2 imbricated and 3 sheathed 

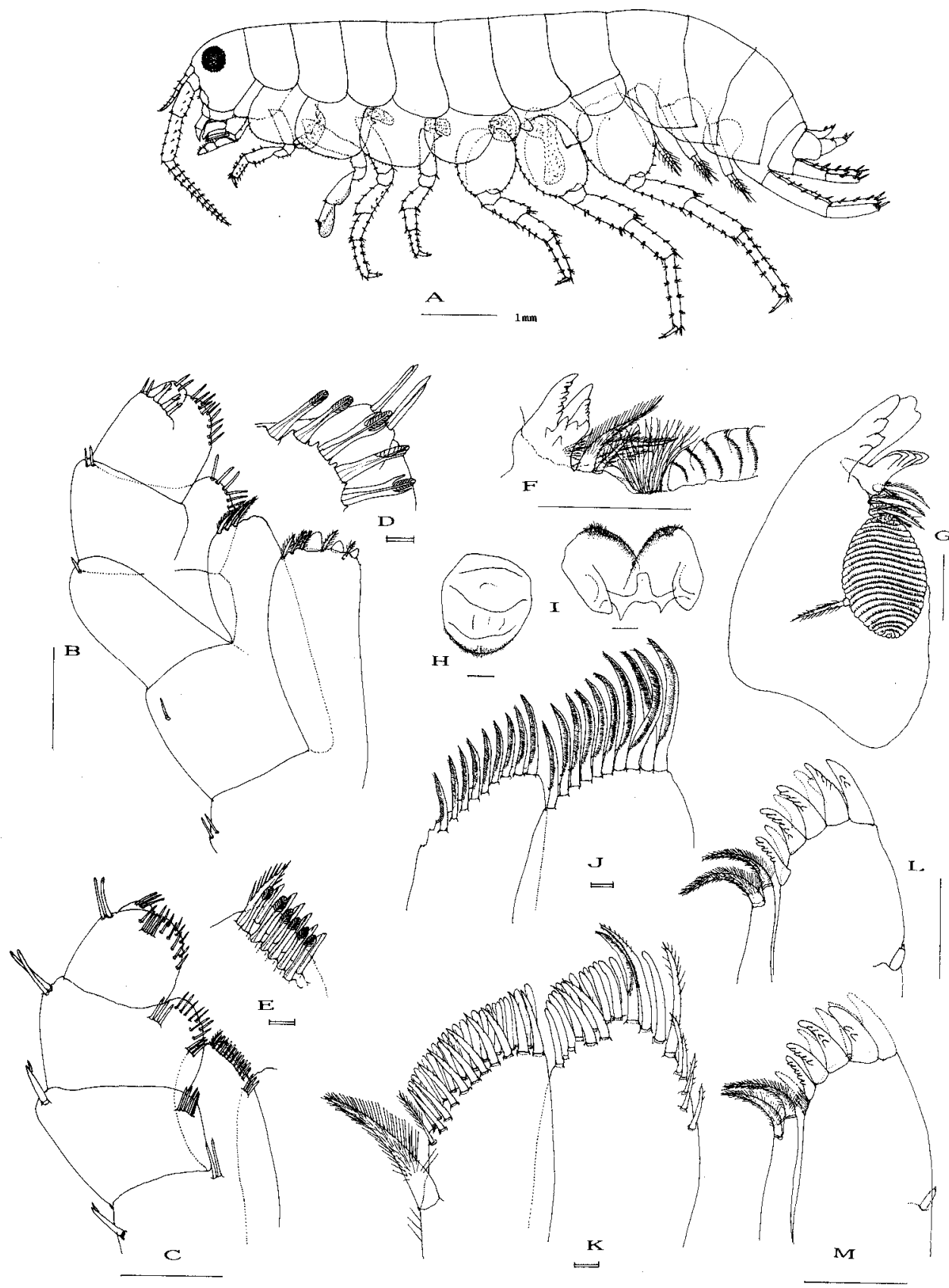

Fig. 11 Platorchestia humicola (Martens) from Tachi. Female $10 \mathrm{~mm}$ : A, lateral view; B and C, dorsal and ventral surfaces of maxilliped; D, a row of distal spines of palp article 3 of maxilliped; E, spines of inner lobe of outer plate of maxilliped; F, lacinia mobilis of right mandible; G, left mandible; $\mathrm{H}$, upper lip; I, lower lip; J and $\mathrm{K}$, ventral side and dorsal side of maxilla 2; $\mathrm{L}$ and $\mathrm{M}$, dorsal and ventral surfaces of maxilla 1 . Bar scales $0.1 \mathrm{~mm}$, double bar scales $0.01 \mathrm{~mm}$. 


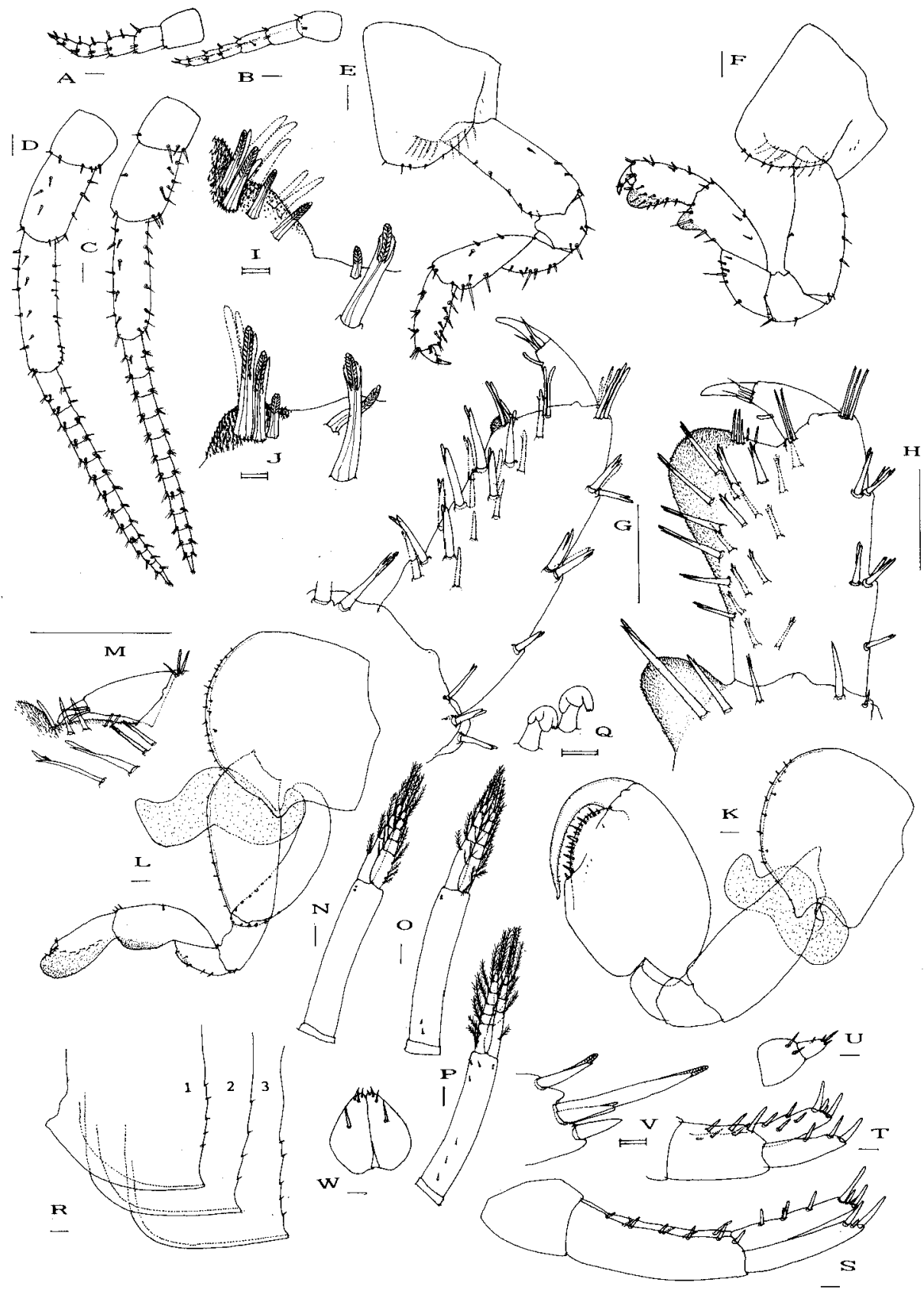

Fig. 12 Platorchestia humicola (Martens) from Tachi. Female $10 \mathrm{~mm}$ and male $8 \mathrm{~mm}$ : A and B, female and male antennae 1; C and D, female and male antennae 2; E and F, female and male gnathopod $1 ; \mathrm{G}$ and $\mathrm{H}$, propods and dactyls of female and male gnathopod $1 ; \mathrm{I}$ and $\mathrm{J}$, posterior end of palm of male and female gnathopod $1 ; \mathrm{K}$ and $\mathrm{L}$, male and female gnathopod $2 ; \mathrm{M}$, dactyl of female gnathopod 2; N-P, pleopods 1-3; Q, retinaculae of pleopod 1; R1-R3, abdominal side plates 1-3; $\mathrm{S}-\mathrm{U}$, uropods $1-3 ; \mathrm{V}$, distal part of ramus of uropod 3; W, telson. Bar scales $0.1 \mathrm{~mm}$., double bar scales $0.01 \mathrm{~m}$. Figures are of female if not mentioned. 


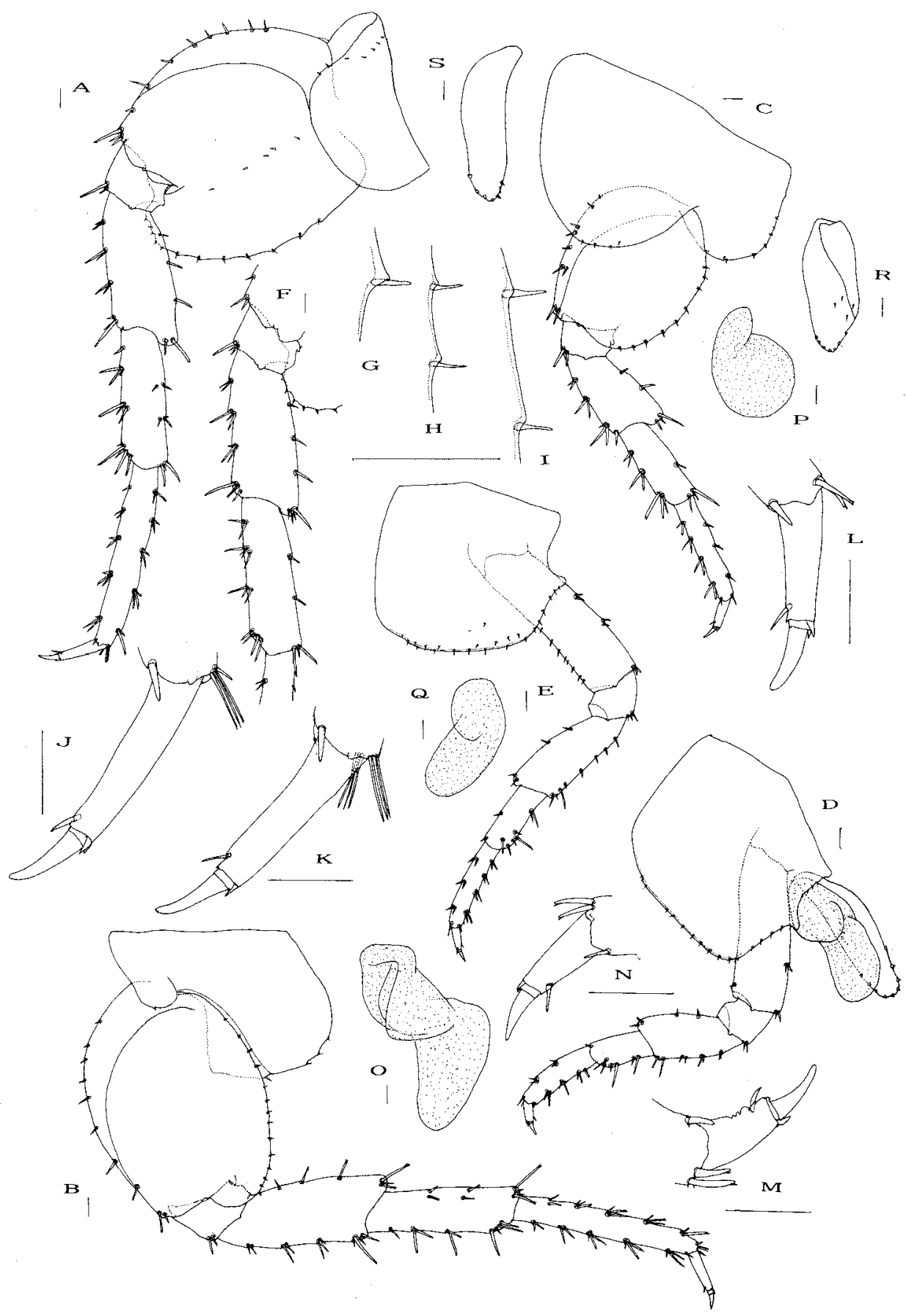

Fig. 13 Platorchestia humicola (Martens) from Tachi. Female $10 \mathrm{~mm}$ and male $8 \mathrm{~mm}$ : A-E, pereopod 7-3; $\mathrm{F}$, ischium-carpus of male pereopod 7; G-I, posteromarginal spines of pereopods 7-5; J-N, dactyls of pereopods 7-3; O-Q, coxal gills of pereopods 6,5 and $3 ; \mathrm{R}$ and $\mathrm{S}$, brood plates 5 and 4 . Bar scales $0.1 \mathrm{~mm}$. Figures are of female if not mentioned. 
spines along base of palp article 4, ventral surface with a transverse row of several imbricated spines on distal part.

Gnathopod 1 (Fig. 12E, G, J): basis parallel sided; propod ca. 0.7 times as long as carpus, with 34 bifid spines on posterolateral margin and with 3-4 bifid spines on lateral surface, with 3-4 bifid spines on posteromedial margin and with 7-8 sheathed spines on medial surface, posterodistal bulge with 2 bifid spines on medial side and with a group of 4 imbricated spines on lateral side; palm very short, oblique, without marginal spines; dactyl lacking denticle, grasping margin of dactyl base with a stiff spine near distal angle. Gnathopod 2 (Fig. 12L, M): coxal plate deeper than wide, ventral margin convex, posterior cusp acute; merus shorter than ischium, posterodistal corner weakly tumescent; propod ca. 0.8 times as long as carpus; dactyl base with 2 stiff spines on grasping margin.

Pereopod 3 (Fig. 13E, N): coxal plate as wide as deep, ventral margin weakly convex; carpus ca. 0.7 times as long as merus; propod ca. 1.2 times as long as carpus. Pereopod 4 (Fig. 13D, M) ca. 0.8 times as long as pereopod 3; coxal plate wider than deep, anteroventral corner almost right-angled, ventral margin straight; carpus ca. 2.0 times as long as wide; propod ca. 1.4 times as long as carpus; dactyl weakly pinched. Pereopod 5 (Fig. 13C, I, L) subequal to pereopod 3 in length; anterior lobe of coxal plate much broader (ca. 2.0 times) and slightly deeper than posterior lobe (ca. 1.4 times), ventral margin rounded, spinose; basis oblong, distal half of anterior margin almost straight; propod ca. 1.2 times as long as carpus. Pereopods 6 and 7: ca. 1.5 times as long as pereopod 3, propod ca. 1.3 times as long as carpus, with 2 groups of 3 spines distally. Pereopod 6 (Fig. 13B, H, K); posterior lobe of coxal plate with right-angled anterodistal corner, the corner not projected ventrally; basis elliptic. Pereopod 7 (Fig. 13A, G, J) basis subcircular, with a longitudinal row of several minute spines along axis on inner surface, posterior margin serrated sparsely.

Coxal gill of gnathopod 2 broadened, longer than basis, anchor-shaped. Coxal gills of pereopods 3-5 (Fig. 13Q, D, P) sac-like. Coxal gill of pereopod 6 (Fig. 13O) leaf-shaped, length ca. 0.5 times as long as basis.

Abdominal side plates 1-3 (Fig. 12R1, 2, 3): posterodistal angles acute, posterior margins weakly serrated.

Pleopods: pleopod 1 (Fig. 12N) shorter than pleopod 2 (Fig. 12O) but longer than pleopod 3 (Fig. 12P), without marginal spines, peduncle of pleopod 3 with a few spines on surface and margins; rami 0.5-0.6 times as long as peduncle, inner rami longer than outer ones, 4-articulated, outer rami 5articulated.

Uropod 1 (Fig. 12S): peduncle with short distolateral spine; rami ca. 0.7 times as long as peduncle, inner ramus with evenly spaced 3 spines on inner margin; outer ramus marginally bare. Uropod 2 (fig. 12T): rami as long as or slightly shorter than peduncle, inner ramus with 2 outer and 2 inner marginal spines, outer ramus with 1 marginal spine. Uropod 3 (Fig. 12U, V): peduncle longer than deep, with 2 spines on subdistal margin; ramus ca. 0.5 times as long as peduncle, with 1 bifid marginal spine or lacking, with 1-2 bifid spines subapically and with a group of 1 long bifid spine and 1 short smooth spine apically.

Telson (Fig. 12W) as wide as or slightly wider than long, apical notch shallow, each lobe with a group of 3 spines apically and 1 spine dorsally.

Brood plates of pereopods 2-4 subequal to or shorter than basis and ischium combined, with simple tipped setae on distal half margin. Brood plate of pereopod 5 (Fig. 13R) shortest, with a few minute spines both on surface and posterior submargin, with several simple tipped setae.

\section{Male}

Body length 7-8 mm. Antenna 1 (Fig. 12B): flagellum ca. 0.6 times as long as peduncle, 4articulated. Antenna 2 (Fig. 12D): peduncular article 5 ca. 1.7 times as long as article 4, slightly thicker than that of female; flagellum ca. 1.9 times as long as peduncular article 5, 12-14 articulated.

Gnathopod 1 (Fig. 12F, H, I): propod ca. 0.6 times as long as carpus, lateral side with evenly spaced 5-6 sheathed spines along base of tumescence and with 2-3 sheathed spines on surface and 


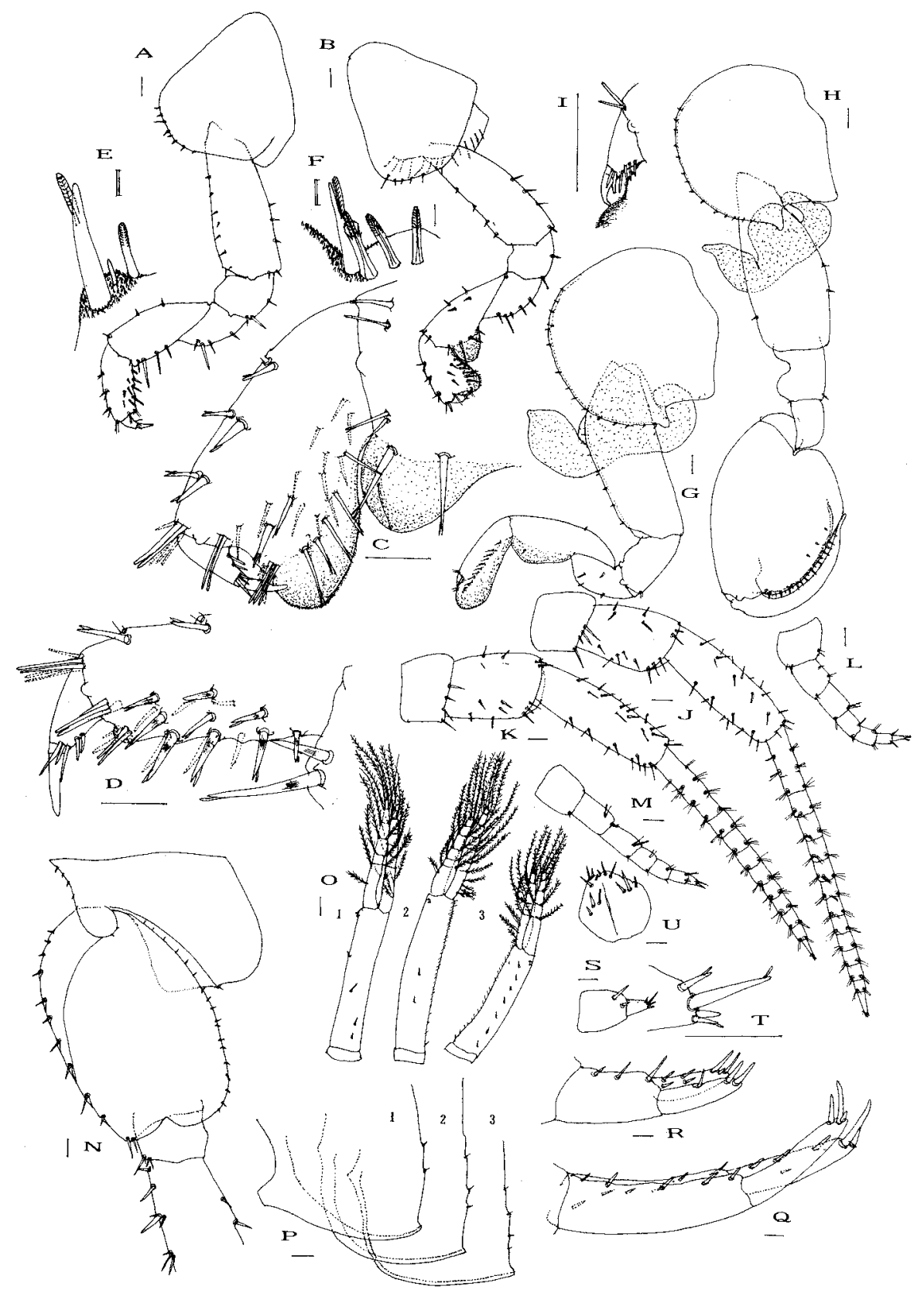

Fig. 14 Platorchestia humicola (Martens) from Kamakura, Japan. Male $8 \mathrm{~mm}$ and female $9 \mathrm{~mm}$ : A and B, female and male gnathopod $1 ; \mathrm{C}$ and $\mathrm{D}$, propods and dactyls of male and female gnathopods $1 ; \mathrm{E}$ and $\mathrm{F}$, posterior end of palm of female and male gnathopod 1 (medial side); $\mathrm{G}$ and $\mathrm{H}$, female and male gnathopod 2; I, dactyl of female gnathopod 2; J and $\mathrm{K}$, female and male antennae 2; $\mathrm{L}$ and $\mathrm{M}$, female and male antennae 1; N, coxal plate and basis of pereopod 6; O1-O3 pleopods 1-3; $\mathrm{P1}$ P3; abdominal side plates 1-3; Q-S, uropods 1-3; T, distal part of ramus of uropod 3; U, telson. Bar scales $0.1 \mathrm{~mm}$. Figure are of male if not mentioned. 
medial side with 11-12 sheathed spines on surface; palmar margin weakly concaved, posterior end of palm with a group of 3 imbricated spines on lateral side and with a group of 2 bifid spines on medial side; tip of dactyl not exceeding posterior distal angle. Gnathopod 2 (Fig. 12K): basis with few spines on both anterior and posterior margins; propod oval, posterior margin gently convex, with $3-4$ spines along palm, palm gently convex; dactyl narrowing distally, slightly longer than palm.

Carpus of pereopod 7 (Fig. 13F) not incrassate.

Coxal gill of gnathopod 2 (Fig. 12K), distal part spade-shaped.

Uropod 1: inner ramus with 4 spines (proximal one very short) on inner margin and 1 spine on outer margin. Uropod 2: outer ramus with 2 marginal spines.

\section{Remarks}

Platorchestia humicola was first described by Martens (1868) from Yokohama, Japan, but he did not describe characters in detail nor give any figure. Weber (1892) and Stebbing (1906) also redescribed it roughly. The material from Taiwan are different from type material deposited at Berlin Museum as well as from Japanese material (Fig. 14) in having: 1) the coxal gill of gnathopod 2 beltshaped (vs. with spade-shaped distal lobe); 2) propod of female gnathopod 1 without transverse rows of 3 bifid spines on lateral surface (vs. with the transverse rows); 3) dactyl of female gnathopod 2 with 2 stiff spines on grasping margin (vs. 3-4 stiff spines); 4) ramus of uropod 3 with 1 bifid marginal spine (vs. without marginal spines). $P$. humicola is similar to $P$. japonica and is separated from the latter by the characters of the key.

\section{Distribution in Taiwan}

This species was found from under fallen leaves and grass (Demao, Shuilien, Tachi) in the coastal area of the north region and a kitchen garden near coast of (Fulung) in mainland (Fig. 15).

\section{Acknowledgment}

The authors wish to express their gratitude to Dr. W.-H. Chou, National Museum of Natural Science of Taiwan for co-operation in this study of Taiwanese talitrid amphipods. The authors wish to thank Dr. Bousfield, Research Associate, Royal Ontario Museum, Toronto, On Canada for his helpful comments, and for critical reading the manuscript. The authors are indebted to the curator of Berlin Museum for the loan of Martens' specimens, to Dr. Wildish for donation of English materials, and to the late Dr. Jo for donation of Korean materials.

\section{References}

Bousfield, E. L. 1982. The amphipod superfamily Talitridae in the northeast Pacific region. 1. Family Talitridae: systematics and distributional ecology. National Museums of Canada, Ottawa, Publications in Biological Oceanography, 11: 1-73.

Bulycheva, A. I. 1957. The sand flea of the sea of USSR and adjoining waters (AmphipodaTalitridae). Key to the fauna of the USSR. Opredeliteli po Faune SSSR, Akademia Nauk SSSR, 65: 1-199. (in Russian).

Chilton, C. 1921. Fauna of Chilka Lake: Amphipoda. Memoirs of Indian Museum, 5 (8): 519-558.

Derzhavin, A. N. 1937. Talitridae of the Soviet coast of the Japan Sea. Issledovanye Faune Morej SSSR, 23: 87112. (in Russian with English summary).

Gurjanova, A. F. 1951. Gammaridea of the seas of the USSR and adjacent waters (Amphipoda-Gammaridea). Opredeliteli po Faune SSSR, Akademia Nauk SSSR, 41: 1-1092. (in Russian).

Holmquist, J. G. 1982. The functional morphology of gnathopods: importance in grooming,and variation with regard to habitat, in talitroidean amphipods. Journal of Crustacean Biology, 2 (2): 159-179.

Iwasa, M. 1939. Japanese Talitridae. Journal of the Faculty of Science, Hokkaido Imperial University, series VI, Zool., 6 (4): 255-296.

Jo,Y. W. 1988. Talitridae (Crustacea-Amphipoda) of the Korean coasts. Beaufortia, 38 (7): 153-179. 


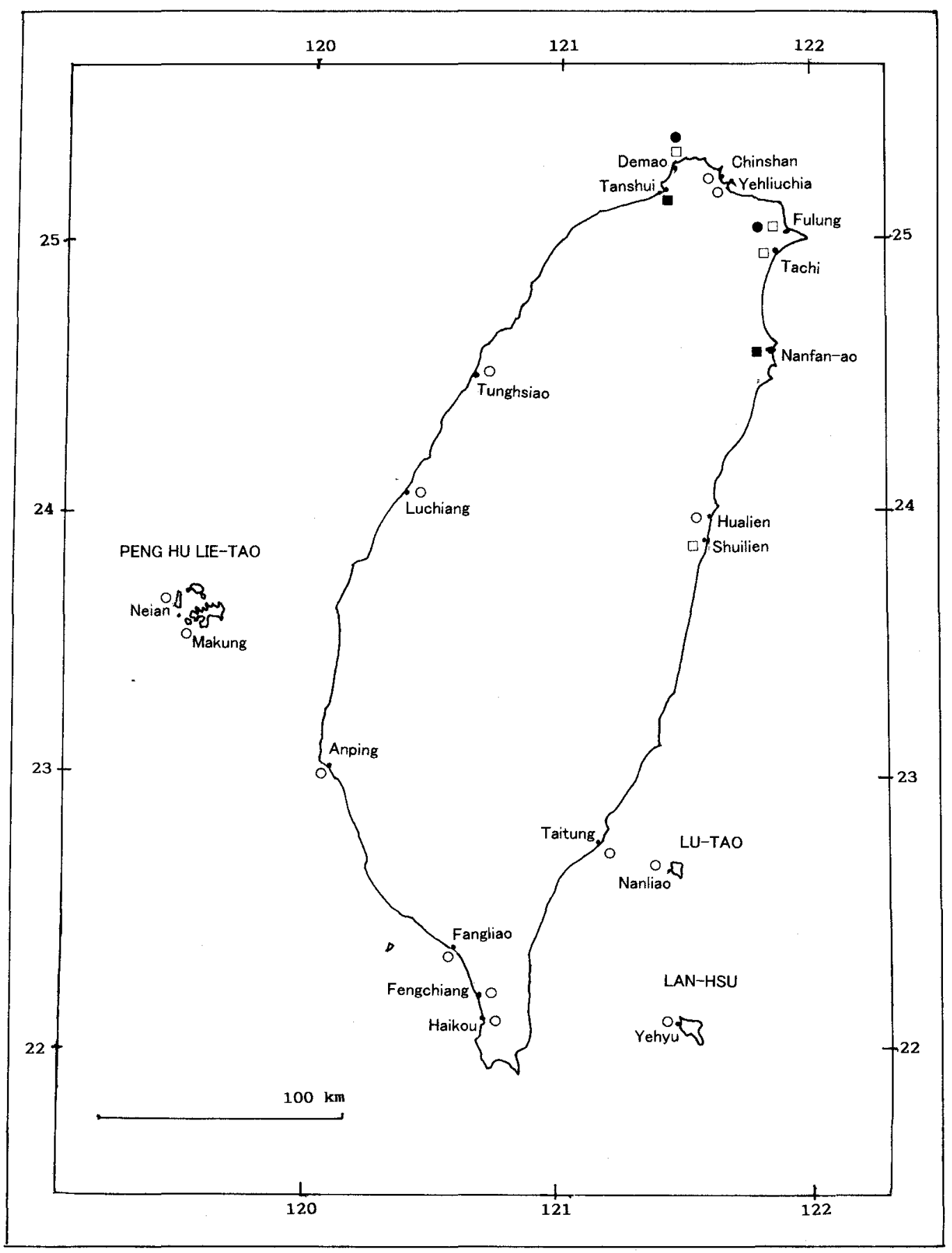

Fig. 15 Distribution of Platorchestia species in Taiwan.

: P joi. $\bigcirc:$ P pacifica n. sp. $\square$ : P. japonica. $\square:$ P. humicola. 
Kim, H. S. \& Kim, C. B. 1987. Marine gammaridean Amphipoda (Crustacea) of Cheju Island and its adjacent waters, Korea. Korean Journal of Systematic Zoology, 3 (1): 1-23.

Martens, E. V. 1868. Über einige ostasiatishe Susswasserthire. Archiv fur Naturgeschichte, Berlin, 34: 1-64

Miyamoto, H \& Morino, H. 1999. Taxonomical studies on the Talitridae (Crustacea, Amphipoda) from Taiwan. I. The genera Talorchestia and Sinorchestia n. gen. Publications of the Seto Marine Biological Laboratory, 38 (5/6): 169-200.

Moore, P. G. 1986. Preliminary notes on a collection of Amphipoda from Hong Kong. In, Morton, B, (Ed.). Proceeding of the second international marine biological workshop: the marine flora and fauna of Hong Kong and Southern China, Hong Kong University Press; Hong Kong, 503-513.

Morino, H. 1975. Studies on the Talitridae (Amphipoda Crustacea) in Japan. II. Taxonomy of sea-shore Orchestia with note on the habitat of Japanese seashore talitrids. Publications of the Seto Marine Biological Laboratory, 22 (1/4): 171-193.

Morino, H. 1999. Amphipoda. In, Aoki, J. (ed.) Pictorial Keys to Soil Animal of Japan. Tokai University Press: pp.65-66, figs. 213-219. (In Japanese).

Morino, H \& Dai, A. 1990 Three amphipod species (Crustacea) from east China. Publications of the Itako Hydrobiological Station, 4: 7-27.

Morino, H. \& R. Ortal. 1995 Two Platorchestia species (Amphipoda: Talitridae) from Israel. Crustaceana, 68 (7): 824-832.

Myers, A. A. 1985. Shallow-water, coral reef and mangrove Amphipoda (Gammaridea) of Fiji. Records of the Australian Museum, Supplement 5: 1-143.

Oshel, P. \& Steel, D. H. 1988. Comparative morphology of amphipod setae, and a proposed classification of setal types. Crustaceana, Supplement 13:90-99.

Richardson, A. M. M. 1991. Two new species of landhoppers (Crustacea: Talitridae) from O ahu Hawaiian Islands, with redescription of Platorchestia pickeringi and key to the landhoppers $\mathrm{O}$ 'ahu. Bernice P. Bishop Museum Occasional Papers, 31: 185-201.

Stebbing, T. R. R. 1906. Amphipoda I. Gammaridea. Das Tierreich, Lief 21, Berlin. 1-806.

Stephensen, K. H. 1945. Some Japanese Amphipod. Viedenskabelige Meddelelser fra Dansk Naturhistorisk Forening, 108: 25-88.

Stock, J. H. 1996. The genus Platorchestia (Crustacea, Amphipoda) on the Mid-Atlantic islands, with description of new species from Saint Helena. Miscel-làia. Zoolòica, 19 (1): 149-157.

Stock. J. H. \& Biernbaum, C. K., 1994. Terrestrial Amphipoda (Talitridae) from Ascension and Saint Helena (South Central Atlantic). Journal of National History, 28: 795-811.

Tattersall, W. M. 1922. Zoological results of a tour in the Far East. Amphipoda with notes on an additional species of Isopoda. Memoirs of the Asiatic Society of Bengal, 6: 437-495.

Watling, L. 1989. A classification system for crustacean setae based on the homology concept. In, Felgenhauer, B. E., Watling, L. \& Thistle A. B. (eds.) Functional Morphology of Feeding and Grooming in Crustacea. Crustacean Issues, 6: 15-27 Balkema, Rotterdam, Brookfield.

Weber, M. 1892. Die Süswasser-Crustacean des Indishen Archipels, nebst Bemerkungen uiber die Süswasser-fauna im Allegemeinen. In, Weber, M (ed.) Zoolgische Ergebnisse einer Reise in Niederlädisch. Ost-Indien, 2: 528-571. 